\title{
Chrome in Türkiye in Terms of Economic Geography
}

\author{
Nuran Taşligil*, Güven Şahin **
}

* Marmara Üniversitesi, **ístanbul Üniversitesi

E-mail: ntasligil@marmara.edu.tr*,sahinguven0@gmail.com**

Copyright (C) 2015 Nuran Taşlıgil, Güven Şahin. This is an open access article distributed under the Eurasian Academy of Sciences License, which permits unrestricted use, distribution, and reproduction in any medium, provided the original work is properly cited.

\begin{abstract}
It is guessed that the quantity of the reserves of chrome which is one of the important export product in Türkiye, is 242 million tones located in 137 mines. Even though the number mentioned above seems a lot, the chromide depostits having a strategical location in terms of transportation, the ones close to the harbours or the ones having a high grade of ore have been operated and many of these are consumed for about 150 years. The reason why the costs have been increasing is because not ony the rest of the mines are poor in terms of the ore grade, but also the ones which are closer to earth are consumed and this issue led the mining operations to go deeper. It is wrong to keep selling chrome as an ore. It's necessary that it would be exported as ferrochromium in Türkiye, as many other countries. On the contrary ferrochromium plants are not enough for that requirement stated above. This study the histrorical development process, quantity and geographical distribution of chrome in our country which posseses a very high strategical importance for whole world.
\end{abstract}

Keywords: Metallic mineral, raw material, chrome/chromite, reserve, production, export, Economic geography, Türkiye.

JEL-Clasification: K00, B0, E20

\section{Ekonomik Coğrafya Açısından Türkiye'de Krom}

\section{ÖZET}

Türkiye'nin tarihsel süreçte önemli ihraç ürünlerinden biri olan kromun günümüz itibariyle 137 yatakta toplam 242 milyon ton rezervi olduğu tahmin edilmektedir. Yaklaşık 150 yıldır özellikle yol durumu iyi, limanlara yakın ve yüksek tenörlü kromit yatakları işletilmiş ve bunların büyük bir kısmı tükenmiştir. Geri kalanların büyük bir kısmı düşük tenörlü olup ayrıca yüzeye yakın olanlar tükendiğinden çoğu bölgede işletmeler derine inmekte bu yüzden maliyet de yükselmektedir. Kromun çok uzun süre cevher olarak satılmasına devam edilmesi yanlıştır. Birçok ülke gibi Türkiye'nin de ferrokrom olarak ihraç etmesi gerekirken maalesef mevcut tesisler bunun için yeterli değildir. Bu çalışmada sadece Türkiye değil dünya için oldukça stratejik bir öneme sahip olan kromun ülkemizdeki tarihsel süreçteki gelişimi ve bunun coğrafi dağılımı üzerinde durularak bu alanda yapılması gerekenler ele alınmıştır.

Anahtar Kelimeler: Metalik maden, hammadde, krom/kromit, rezerv, üretim, ihracat, Ekonomik coğrafya, Türkiye. 


\section{Giriş}

Madencilik dünyanın en eski iktisadi faaliyetlerinden birisidir. Madencilik alanında kaydedilen gelişmeler, işlenen hammaddeler ve bunlardan elde edilen araç gereçler insanlık tarihinin gelişiminde büyük rol oynamış ve söz konusu madenlerin adıyla anılan tarihsel devirlerle özdeşleşmişlerdir. Demir, bakır, altın ve gümüş başta olmak üzere çok sayıda maden insanlık tarihinde dikkat çekici bir rol üstlenmişlerdir. Bunlardan bir kısmı nadide olması bir kısmı ise sanayileşmenin temel taşı olması açısından öne çıkmıştır. Bu çalışmada ele almış olduğumuz krom ise insanlık tarihinin hemen hemen en yeni cevherlerinden biri olmasına karşılık çok hızlı ve bir o kadar stratejik bir önem taşıyarak gelişim göstermiştir.

Sanayinin önemli hammaddelerinden biri olan krom, ülkemizde ilk defa 1848 y1lında Bursa yakınlarında (Harmancık) bulunmuş, 1868'den bu yana önemli ihraç ürünlerimizden biri haline gelmiştir. Yaklaşık 150 yıldan beri dünya krom piyasasında ilk sıralarda yer alan Türkiye, Güney Afrika Cumhuriyeti'nde de zengin yatakların bulunmasından sonra üstünlüğünü kaybetmiştir.

Yıllar içinde üretim ve ihracatta dünya piyasasının durumuna göre önemli dalgalanmalar olsa da Türkiye'nin krom üretimi artarak son yıllarda 3.000.000 tona yaklaşmıştır. Üretimdeki bu artışa paralel olarak ihracatımızda da büyük artışlar meydana gelmiştir. Bu çalışmada kromun genel özellikleri, kullanım alanları, tarihsel gelişimi, ihracatı ve ithalatı ile ülke çapındaki rezervlerin miktar ve dağılımı ele alınmıştır. Sonuç olarak da Türkiye'nin krom pazarında hala stratejik bir pozisyonda oluşu, ihracatla birlikte kendi ihtiyacının da artma eğiliminde olması, stratejik kaynaklar grubunda yer alan bu kaynakla ilgili yapılması gerekenler, alınabilecek tedbirler ve izlenmesi gereken politikalar hakkında önerilerde bulunulmuştur.

\section{Kromun Genel Özellikleri ve Tarihsel Gelişimi}

Yerkabuğunun doğal bileşimlerinden biri olan krom, sanayi açısından hayati bir öneme sahiptir. Yeryüzünde krom içeren 25 kadar mineral bilinmekte olup en önemlileri kromit, uvarovit, fuksit ve kemererittir. Bunlardan kromit en yaygın krom minerali olup genellikle krom yatakları yerine kromit yatakları olarak da adlandırılmaktadır. Kromit, yerkabuğunda bulunan mineraller içerisinde miktar bakımından 21. sırada yer almakta bir başka ifadeyle de yerkabuğunun kabaca \% 0.037'sini kromit oluşturmaktadır (Çakmak, 2006; 20). Kromitler genel olarak $\mathrm{Mg}$ ve Fe içeriklerine göre magnezyum kromit ve ferrokrom şeklinde $\mathrm{Al}$ ve $\mathrm{Fe}$ içeriklerine göre de alüminyum kromit ve ferrokrom şeklinde isimlendirilmektedir. Kromit $\mathrm{FeCr}_{2} \mathrm{O}_{4}$ şeklinde formüle edilmekle birlikte krom bunun içerisindeki oranı ifade eder ve $\mathrm{Cr}_{2} \mathrm{O}_{3}$ olarak formüle edilir. Kromit, $\mathrm{Mg}, \mathrm{Cr}, \mathrm{Fe}, \mathrm{Al}$ elementlerini de içermekle beraber yataklanma özelliklerinden dolayı yaygın olarak silis de oldukça yaygın bir şekilde bulunur. Silis krom madenciliğinde istenmeyen bir mineral olup başlıca gang mineralini teşkil etmekte ve maliyeti artırmaktadır. Fiziksel özellikleri açısından da kromit kütleleri birkaç cm.'den 100 m.'yi aşan uzunluğa ulaşabilmekle beraber ekseriyetle 4 - 5 m.'ler civarında gözlenmektedir. Kalınlıkları ise ortalama 2 - 3 m. olup 5 m.'yi aşanlara da rastlanmıştır (DPT, 2007; 21).

Genel özellikleri itibariyle kromit; parlak, koyu kahverenginden siyaha kadar değişen renklerde olabildiği gibi sarı, kırmızı ve yeşil tonlarında da değişik krom minerallerine rastlanabilmektedir. Atom numarası 24, özgül ağırlı̆̆ $4.1-4.9 \mathrm{gr} / \mathrm{cm}^{3}$, sertliği 5.5, kaynama sicakl 1 ğ $2671^{\circ} \mathrm{C}$, ergime sicakl $1 \breve{g ̆}_{1} 1890^{\circ} \mathrm{C}$ olan bir mineraldir. Burada dikkat çekilmesi gereken bir diğer ve en önemli nokta kromun ergime sıcaklığıdır. Sanayide kullanılan pek çok metale kıyasla ergime derecesindeki yükseklik kromu ayrıca değerli kılmaktadır. Örnekleriyle 
izah edecek olursak kromun ergime derecesi $1890^{\circ} \mathrm{C}$ iken sirasiyla titanyum $1730^{\circ} \mathrm{C}$, demir $1539^{\circ} \mathrm{C}$, kobalt $1495^{\circ} \mathrm{C}$, nikel $1455^{\circ} \mathrm{C}$, bakır $1083^{\circ} \mathrm{C}$, altın $1063^{\circ} \mathrm{C}$, alüminyum $660^{\circ} \mathrm{C}$, çinko $419^{\circ} \mathrm{C}$, kurşun $327^{\circ} \mathrm{C}$ ve kalay $232^{\circ} \mathrm{C}$ ergime derecesine sahiptir. Bahsi geçen söz konusu metallerin ergime dereceleri ve sanayideki kullanım alanları düşünüldügünnde kromun içlerinde ne kadar önemli bir yere sahip olduğu bir defa daha anlaşılmaktadır ${ }^{1}$.

Kromit minerali, krom içeriğine göre ise;

a) Metalürjik krom cevheri (Yüksek kromlu cevher)

b) Kimyasal krom cevheri (Yüksek demirli cevher)

c) Refrakter krom cevheri (Yüksek alüminyumlu cevher) üçe ayrılır.

Kromun tarihsel süreçteki gelişimine de kısaca bakacak olursak çoğu madenin aksine kromun insanlık tarihindeki geçmişi oldukça kısadır denebilir (Tablo 1). Her ne kadar 1762'de ilk olarak Alman Mineralog ve Jeolog Johann Gottlob Lehmann (1719 - 1767) tarafindan Rusya'nın Ural Dağları civarında krom içeren mineraller bulmuş olsa da söz konusu bu buluşu inceleyip periyodik cetvele sokan Vauquelin olmuştur. Louis Nicolas Vauquelin (1763 - 1829) krom içeren mineralleri analiz etmiş ve en nihayetinde Lehmann'ın keşfinden yıllar sonra, 1797'de Krom (İng. Chrome, Alm. Chrom) adını vererek sınıflamasını yapmıştır (Enver, 1931; 1, Rüstow, 1944; 26, Zeytinoğlu, 1970; 266). Bu adın verilmesinde kromun tabiattaki bulunuş rengi etkili olmuştur. Oldukça parlak, çeşitli renk ve tonlarda bulunabilen krom içeren minerallerden ve alaşımlarından dolayı Vauquelin, Yunanca renk anlamına gelen chroma adını vermiştir. Bu buluştan itibaren kromun medeniyet tarihinde kabaca 200 yıllık bir geçmişi vardır denebilir (Tablo 1).

Krom, başlangıçta pek de yaygın bir kullanım alanı bulamamış olmakla birlikte ilerleyen yıllarda sanayi alanında hem yoğun hem de çeşitli bir tüketim alanına kavuşmuştur. Şüphesiz ki en yoğun rağbet gördüğü alan metalürji sektörü olup özellikle de metallerin paslanmaya karşı olan direncini artırmasıyla çelik sektöründe adeta bir devrim yaşanmıştır. Söz konusu kromun bu özelliği ise bir rastlantıya dayanmaktadır. 1913'te İngiliz Metalurjist Harry Brearley (1871 - 1948) isimli araştırmacı top namlusu dökümü ile ilgili çalışması esnasında bazı metallerin paslanmadığını fark etmiş olup yaptığı analizler neticesinde bunun krom olduğunu görmüştür (Kıdıman, 2009; 3). Böylece paslanmaz çelik keşfedilmiş olundu ve dünya sanayisinde yeni bir dönem başladi.

1 Çeşitli metal ve alaşımların erime noktaları $\left({ }^{\circ} \mathrm{C}\right)$ hakkında daha detaylı bilgi için bkz.
http://www.haddemetal.com/tr/Download/Metallerin $\% 20$ Erime $\% 20 \mathrm{ve} \% 20$ Kaynama\%20Noktalari.pdf
(Son 28.04.2015) 


\begin{tabular}{|c|c|}
\hline YIL & AÇIKLAMA \\
\hline 1762 & $\begin{array}{l}\text { Alman Mineralog ve Jeolog Johann Gottlob Lehmann tarafindan Rusya'nın Ural } \\
\text { Dağları civarında ilk olarak krom içeren mineraller (krokoit) keşfedilmiştir. }\end{array}$ \\
\hline 1797 & $\begin{array}{l}\text { Fransız Kimyacı Louis Nicolas Vauquelin kromu analiz ederek literatüre } \\
\text { kazandırmış ve isim babası olmuştur. }\end{array}$ \\
\hline 1811 & Bilinen ilk büyük kromit yataklarının keşfi A.B.D.'de gerçekleşti. \\
\hline 1828 & Çelik üretiminde katkı maddesi olarak kullanılmaya başlandı. \\
\hline 1830 & Norveç’te krom madenciliği başladı. \\
\hline 1848 & $\begin{array}{l}\text { Türkiye'de ilk olarak Amerikalı Kimyager ve Akademisyen John Lawrence } \\
\text { Smith tarafindan krom keşfedildi. }\end{array}$ \\
\hline 1849 & Hindistan'da krom bulundu. \\
\hline 1850 & $\begin{array}{l}\text { Türkiye'de iktisadi bir faaliyet olarak krom madenciliği ile birlikte ihracatta } \\
\text { başladı. }\end{array}$ \\
\hline 1858 & Dericilikte kullanılmaya başlandı. \\
\hline 1879 & İlk olarak Fransa' da refrakter sanayide kullanılmaya başlandı. \\
\hline 1882 & Avustralya'da krom bulundu. \\
\hline 1887 & Fethiye - Üçköprü kromit yatakları ruhsat alarak işletilmeye başlandı. \\
\hline 1893 & Almanya'da ilk defa zırh kaplaması için ferrokrom üretildi. \\
\hline 1906 & Dünya krom üretimi 100.000 tona ulaştı. \\
\hline 1906 & Rodezya (Bugünkü Zimbabwe)'da krom bulundu. \\
\hline 1913 & Harry Brearley tarafindan krom kullanılarak paslanmaz çelik elde edildi. \\
\hline 1915 & Elazığ'da krom bulundu. \\
\hline 1918 & İlk modern ferrokrom tesisi kuruldu. \\
\hline 1936 & Guleman Krom Yatağı, Etibank’a devredildi ve Şark Kromları T.A.Ş. kuruldu. \\
\hline 1937 & Filipinler ve Arnavutluk'ta krom yatakları bulundu. \\
\hline 1939 & $\begin{array}{l}\text { Şark Kromları T.A.Ş. Etibank'a bağlandı ve Etibank Şark Kromları İşletmesi } \\
\text { Müessesesi adı altında faaliyetlerine devam etti. }\end{array}$ \\
\hline 1940 & $\begin{array}{l}\text { Türkiye ile müttefikler arasında } 8 \text { Ocak } 1940 \text { tarihinde Krom Antlaşması } \\
\text { imzalandı. }\end{array}$ \\
\hline 1943 & İlk defa salt ferrokrom üretim sitesi Kazakistan (S.S.C.B.)'da kuruldu. \\
\hline 1948 & Türkiye 1948 'den 1952 yılına değin dünya krom üretiminde 1 . sırada yer ald1. \\
\hline 1950 & $\begin{array}{l}\text { Türk Maadin Şirketi tarafından Kavak (Eskişehir) kromlarını zenginleştirmek } \\
\text { amacıyla ilk modern zenginleştirme tesisi kuruldu. }\end{array}$ \\
\hline 1963 & Antalya'da ferrokrom üretimi başladı. \\
\hline 1965 & $\begin{array}{l}\text { Şark Kromları İşletmesine bağlı olarak Elazı̆̆'da } 150.000 \text { ton/yıl kapasiteli } \\
\text { zenginleştirme tesisi devreye girmiştir. }\end{array}$ \\
\hline 1974 & Yeni Kaledonya'da krom bulundu. \\
\hline 1977 & Elazığ'da ferrokrom üretimi başladı. \\
\hline 1989 & $\begin{array}{l}\text { MTA tarafından Aladağ (Adana)'da dünyanın sayılı zenginlikte olan krom } \\
\text { yatakları keşfedildi. }\end{array}$ \\
\hline 1990 & $\begin{array}{l}\text { Türkiye'nin krom üretimi tarihinde ilk defa } 1 \text { milyon tonu aşmıştır (1.089.942 } \\
\text { Ton) }\end{array}$ \\
\hline
\end{tabular}

Tablo 1: Kromun Kronolojik Gelişimi 


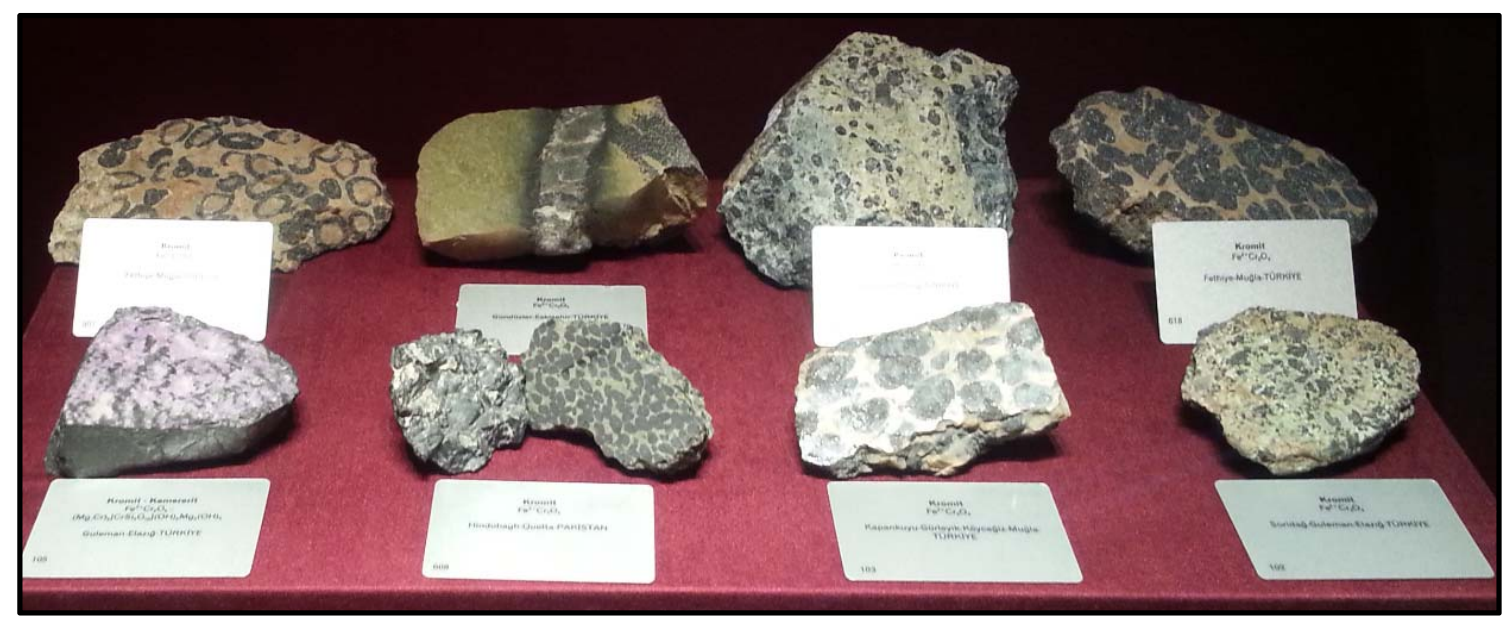

Fotoğraf 1: Türkiye'nin Farklı Yörelerinden Çıkartılan Kromit Cevherleri Örnekleri (MTA Müzesi / Ankara)

Kromun keşfinin ardından kısa bir süre sonra Türkiye'de de iyi kalitede, yüzeye yakın ve nakliye açısından elverişli kromit yatakları keşfedilmiştir. Bu sayede Türkiye uzun bir süre dünya krom pazarında rakipsiz söz sahibi konumunda kalmıştır. Buna örnek olarak 1930'larda dünya krom üretiminin tek başına \% 15 - 20 kadarını sağlaması ve 1948 'den 1952'ye değin dünya krom üretiminde 1. sırada yer alması verilebilir (Tablo 1). İlerleyen yıllarda Güney Afrika Cumhuriyeti, Hindistan, Yeni Kaledonya, Filipinler ve Avustralya'da da kromun keşfiyle birlikte Türkiye krom pazarındaki üstünlüğünü yitirmiş olsa da Avrupa pazarlarına yakınlığı ve iyi kalitedeki kromuyla yine de başlıca ülkeler arasında yer almaktadır.

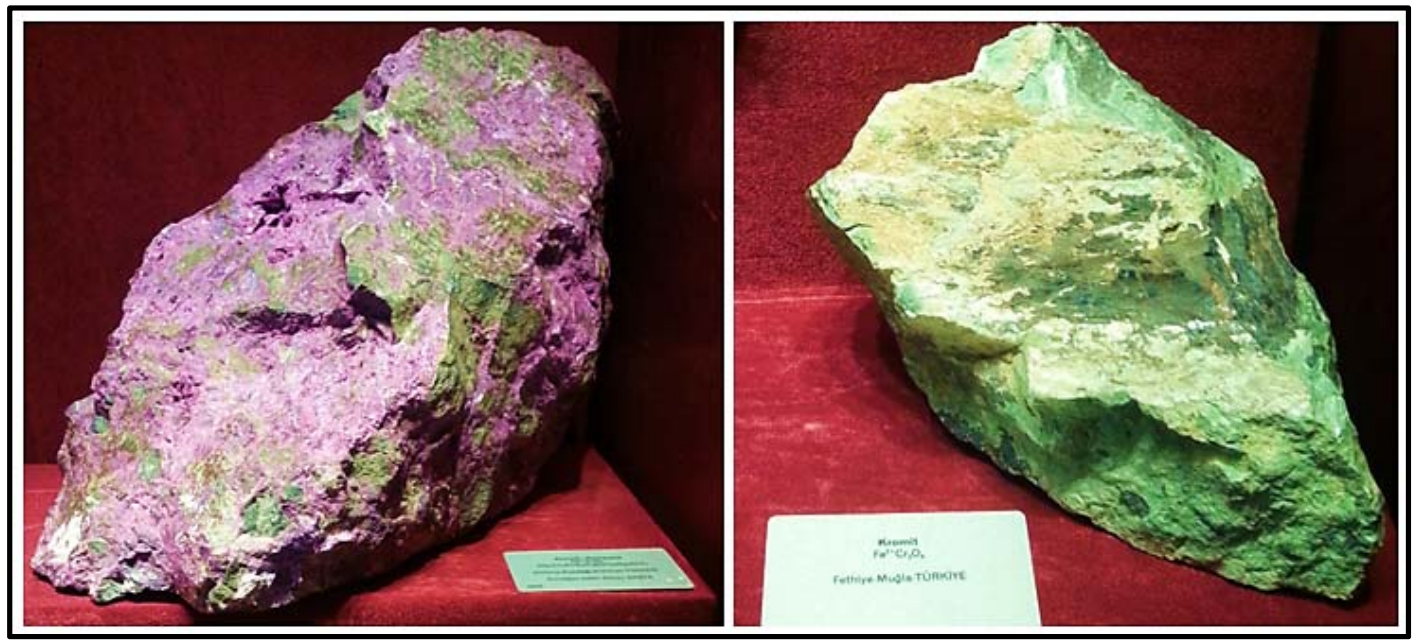

Fotoğraf 2: Solda Krom Minerallerinden Kemererit, Sağda ise Kromit Örneği (MTA Müzesi / Ankara)

Kromun kullanım alanlarından bahsedecek olursak temel tüketim alanı metalürji sanayidir denilebilir. 19. yy.'ın başından itibaren önce metalürji fırınlarında, az miktarda da boya ve deri işleme malzemesi olarak kullanılmaya başlanmış, yüzyılın sonuna doğru ise metalürji ve kimya sanayinde önemli ve stratejik ürünlerden biri haline gelmiştir. İlerleyen yıllarda kromun kullanım alanları çok daha genişlemiş ve temel sanayi faaliyetlerinin en çok aranan hammaddesi olmuştur. Krom cevherinin en önemli kullanım alanı metalürji sanayi olup (Tüm 
dünya kromunun \% 79’u) ferrokrom (çelik) yani kromun demir ile alaşımıdır ${ }^{2}$. Demire \% 70 oranında krom ilave edilerek ferrokrom elde edilmektedir. Yani 1 ton ferrokrom için 2.5 ton krom cevheri gerekmektedir. Ferrokrom, paslanmaz çelik ve silah sanayinin en önemli maddesidir. Krom, çeliğe sertlik, darbelere ve kırılmalara karşı koruma ve en önemlisi paslanmasını engellediğinden normalinden daha uzun bir kullanım ömrü sağlar. Bu nedenle nükleer reaktörler, buhar ve gaz türbinleri, petro-kimya, petrol rafinerileri ve diğer endüstri tesislerinin temel malzemesini teşkil etmektedir. Ayrıca paslanmayı önleyici bir madde olarak uçak ve gemi sanayi, denizaltı yapımında da aranan bir cevherdir. Paslanmaz çelikler \% 12 40 arasında krom içerdiği düşünülecek olursa sektör için önemi daha net anlaşılmaktadır (Can, 2008; 2). Günümüzde paslanmaz çelik üretiminde kromun yerine geçebilen alternatif bir madde henüz bulunabilmiş değildir. Farklı bir şekilde nikel, kobalt, vanadyum, molibden kullanılsa da bunlar krom alaşımlara göre daha pahalı ve daha düşük kalitededirler. Bununla birlikte yurtdışında olduğu gibi Türkiye'de de krom ve de özellikle ferrokrom talebi yıldan yıla kayda değer bir artış göstermektedir. Buradan da kromun stratejik önemini daha uzun yıllar koruyacağı ve ne ölçüde değerli bir kaynak/cevher olduğu bir defa daha anlaşılmaktadır.

Kromun kimyadaki kullanımı kromaj veya krom kaplamadır. Elektroliz yoluyla yapılan bu kaplama sürtünmeye ve aşınmaya karşı direnci nedeniyle bütün mühendislik aletlerinde kullanılır. 1900'lere kadar kimya sanayinde boya pigmenti ve dericilikte sepileme (Krom sepileme) tuzları (Sodyum bikromat, sodyum kromat, potasyum dikromat, kromik anhidrit gibi) olarak kullanılmıştır. Bugün çeşitli boya maddeleri, seramikler, katalizör, konserve kutuları, parlatıcı ürünlerin imali ve sondaj çamuru gibi çok değişik alanlarda işlev görmektedir. Refrakter ${ }^{3}$ sanayine gelince yüksek firınlarda tuğla ve sıva yapımında kullanılır. Refrakter sanayinde kullanılacak kromitin $\mathrm{Cr}_{2} \mathrm{O}_{3}$ içeriğinin en az \% 30 dolaylarında olması gerekmektedir. Tüm bunların yanında döküm sanayi, kaplama malzemesi, çok sayıda yedek parçanın imalinde krom oldukça aranan bir madde olmuştur. Özellikle refrakter ve döküm sanayinde A.B.D., Fransa ve Japonya en büyük tüketicilerdir.

Yukarıda sayılan işlevlerinden dolayı gelişmiş ülkeler bu minerali sürekli temin etmek için arama çalışmalarını yoğunlaştırmış, alternatif madde arama ve hurdalarını değerlendirme çabalarını artırmışlardır. Kromun savunma sanayi ile birlikte tüketim alanının genişlemesi ve eskisi gibi kolay ulaşılabilir özelliğinin yitirilmesiyle stratejik önemi yıldan yıla artmaktadır. Bu nedenledir ki başta A.B.D. olmak üzere çoğu ülke kromu stratejik madenler kategorisinde değerlendirmektedir.

\section{Kromit Yatakları ve İşlenişi}

Krom yatakları, jeolojik ve mineralojik özellikleri açısından üç tipe ayrılmakla beraber ekseriyetle bunlardan ikisi ekonomik değere haiz olduğundan genellikle iki yatak tipinden bahsedilir. Söz konusu yataklar;

1. Stratiform Yataklar: Karakteristik olarak Bushweld (Güney Afrika Cum.) ve Stillwater (A.B.D.)'deki gibi duraylı kıtasal bölgelerde yani kraton sahalarda bulunan stratiform sokulumlara bağlı yataklardır. Adını da bu tabakalı özelliğinden ötürü almaktadır. Kromit kristalleşir ve magmanın içinde belirli seviyeler meydana gelirse stratiform yataklar

\footnotetext{
${ }^{2}$ Bazı kaynaklarda dünyada üretilen kromun \% 90'ından fazlasının metalürji sanayinde kullanıldığı ifade edilmekle birlikte bunun çok abartı bir değer olduğu düşünülmektedir.

${ }^{3}$ Refrakter (Asit ve gazdan etkilenmeyen) ateşe dayanıklı izolasyon malzemesi olan ateş çimentosu, ateş tuğlaları, cam mutfak eşyaları gibi büyük bir malzeme grubu oluşturur.
} 
oluşur. Bu yataklarda kromit kristalleri çok küçüktür ve demir açısından da zengindir. Dünyanın bilinen kromit yataklarının yaklaşık \% 90’ı bu tiptedir.

2. Podiform Yataklar: Ekseriyetle Alpin orojenezine bağlı olarak söz konusu silsile boyunca rastlanmalarından ötürü bu yataklara Alpin Tipi Yataklar da denilmektedir. Stratiform tabakalar magmanın katılaşmasını takiben tektonik olaylar sonucu kırılıp, parçalanıp adeseler, cepler oluşturursa Alpin Tipi yani podiform yataklar meydana gelir. Bazik ve ultrabazik kayaçlara (ofiyolit istiflerine) bağlı kromit yatakları mercek veya düzensiz şekilli, küçük ölçekli yataklardır. Bu yataklarda ise stratiform yatakların aksine kromit kristalleri iri ve demir açısından fakirdirler.

3. Eşmerkezli Yataklar: $\mathrm{Bu}$ yataklar konsantrik bazik ve ultrabazik kayaç topluluklarının eşmerkezli bir iç düzende bulunmalarından adını alır. Günümüz itibariyle ekonomik bir değer ifade etmemekle beraber ilerleyen yıllarda istifade edilebilir.

Günümüzde krom yataklarından kökensel ilişkileri, yapısal konumları ve iktisadi şartlar göz önüne alındığında yukarıda sayılan ilk iki tip yani Stratiform (Tabakalı) ve Podiform (Merceksel) tip yataklar dikkate alınmaktadır.

Alpin tipi yataklar Türkiye'de de olduğu gibi genellikle küçük boyutlu, düzensiz şekilli, mercek, bant, şekilsiz ve karmaşık yapılı yataklardır. Kromit merceklerinin boyutları çoğunlukla birkaç metre kadar olup 100.000 tondan fazla rezerve sahip mercek sayıs1 sınırlıdır. Mercekler çok düzensiz şekillerde olup kalınlıkları, doğrultu ve eğim yönünden de çok değişkenlik gösterir. $\mathrm{Bu}$ yüzden bu tip yatakların aranıp bulunması, rezervlerinin saptanması çok güç olup oluşum özellikleri nedeniyle teknik güçlüklerle karşılaşılmaktadır.

Alpin tipi kromit yataklardaki cevherlerin krom $\left(\mathrm{Cr}_{2} \mathrm{O}_{3}\right)$ oranlarının stratiform yataklardakine göre daha yüksek olması nedeniyle 1970'li yıllara kadar metalürji sanayinde rakipsiz olarak kullanılmışlardır. Bu yüzden 20. yy.'’n ilk çeyreğine kadar kromit üretimi daha çok Alpin tipi yataklardan yapılmıştır. Bundan başka $\mathrm{Cr}_{2} \mathrm{O}_{3}$ içeriği düşük $\mathrm{FeO}$ içeriği yüksek olan stratiform yataklardan üretilen cevher ise 1970'li yıllara kadar genelde kimya sanayiinde kullanılmıştır. 1970'lerde çelik teknolojisinde meydana gelen yenilikler büyük rezervli stratiform tipi yatakların yüksek demirli cevherlerinin metalürji sanayinde kullanılmasını mümkün hale getirmiştir. Bunun sonucunda dünya kromit cevheri rezervlerinin \% 90'ından fazlasını oluşturan stratiform tipi yataklardan üretim hızla artmaya başlamıştır. Yapısal özelliklerine göre üçe ayrılan kromit yatakları ekonomik özelliklerine göre de üçe ayrılmaktadır. Bunlar;

10.000 - 50.000 Ton arasındakiler Küçük Yataklar

50.000 - 200.000 Ton arasındakiler Orta Büyüklükte Yataklar

200.000 - 500.000 Ton arasındakiler Büyük Yataklar olarak gruplandırılır.

Kromit cevherinin en fazla rastlandığı litolojik oluşumlar magmatik derinlik kayaçları ya da metamorfik derinlik kayaçları olup bu madenin filizleri bu kayaçların oluşumuna bağlı olarak cevherleşmişlerdir. Ultrabazik kayaçlardan da özellikle peridodit en fazla kromite rastlanan kayaçtır (Doğanay, Altaş, 2013; 128). Tektonik hareketler yatakları çok karışık duruma sokmuştur. Bu durum ise kromit araştırmalarını güçleştirmekte ve pahalı hale getirmektedir.

Krom zenginleştirme de krom madenciliğinin en önemli basamaklarından biridir. Kromit, yataktan çıkartıldıktan sonra elle ayıklama (triyaj), yıkama, özgül ağırlık farkına göre, manyetik ayırma yöntemleriyle, kimyasal yöntemlerle ve sallantılı masalar kullanılarak 
zenginleştirmeye tabi tutulur. İnce veya düşük tenörlü kırılmış cevherler; jig, sallantılı masa, spiral manyetik ayırıcı yardımıyla konsantre hale getirilir. Ticari olarak $\mathrm{Cr}_{2} \mathrm{O}_{3}$ içeriğine göre $\% 40$ 'dan az olan 3. kalite, $\% 40$ - 46 olan 2 . kalite ve $\% 46$ 'dan fazla olan ise 1 . kalite olmak üzere siniflandırılır. Konsantre kromun \% 46 - 48'i $\mathrm{Cr}_{2} \mathrm{O}_{3}, \% 15$ - 20'si $\mathrm{MgO}, \% 8-15^{\prime} \mathrm{i}$ $\mathrm{Al}_{2} \mathrm{O}_{3}$ ve $6-8$ 'i de $\mathrm{SiO}_{2}$ 'dir (DPT, 2001; 12).

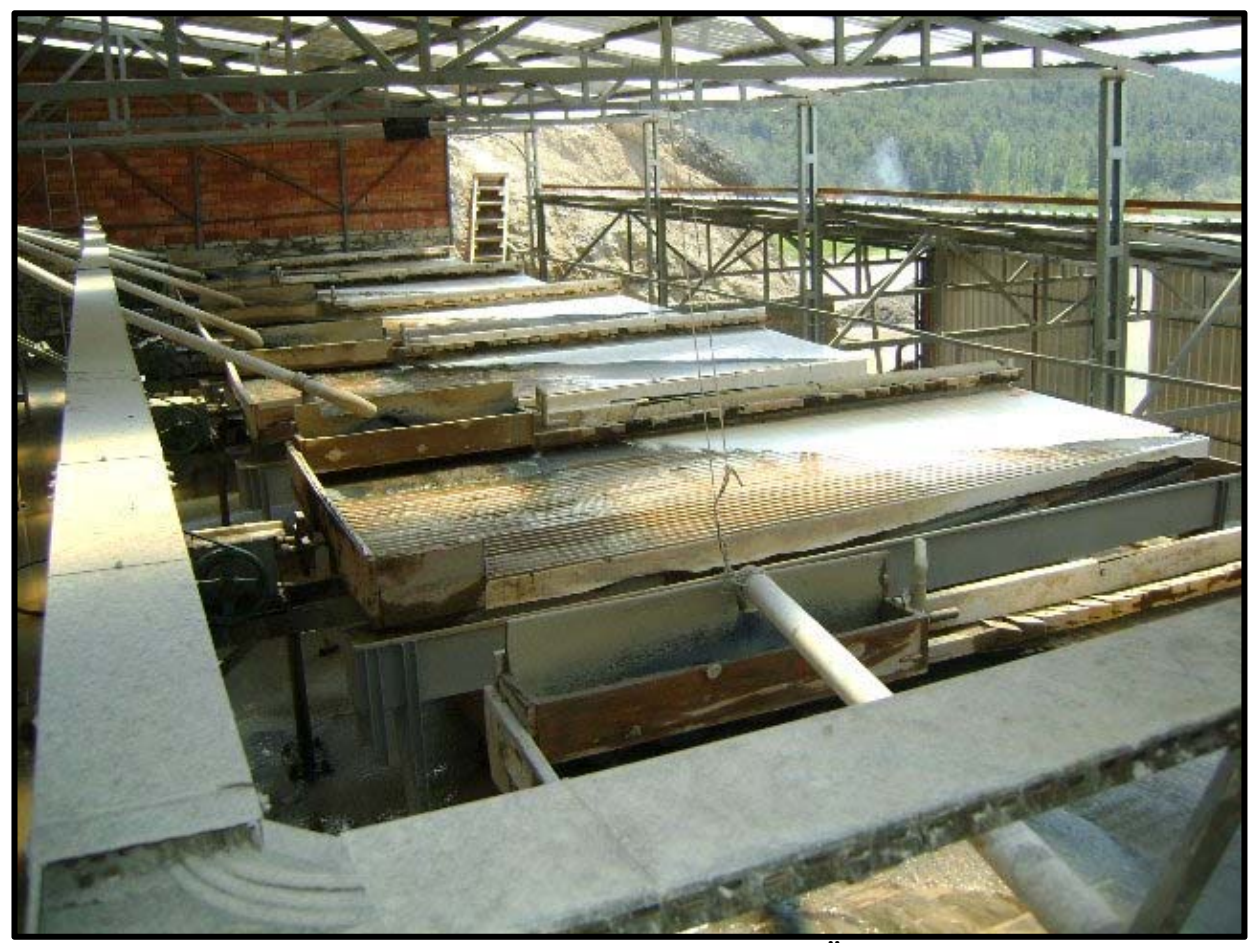

Fotoğraf 3: Sallantılı Masa ile Krom Zenginleştirme Örneği (Bursa - Harmancık)

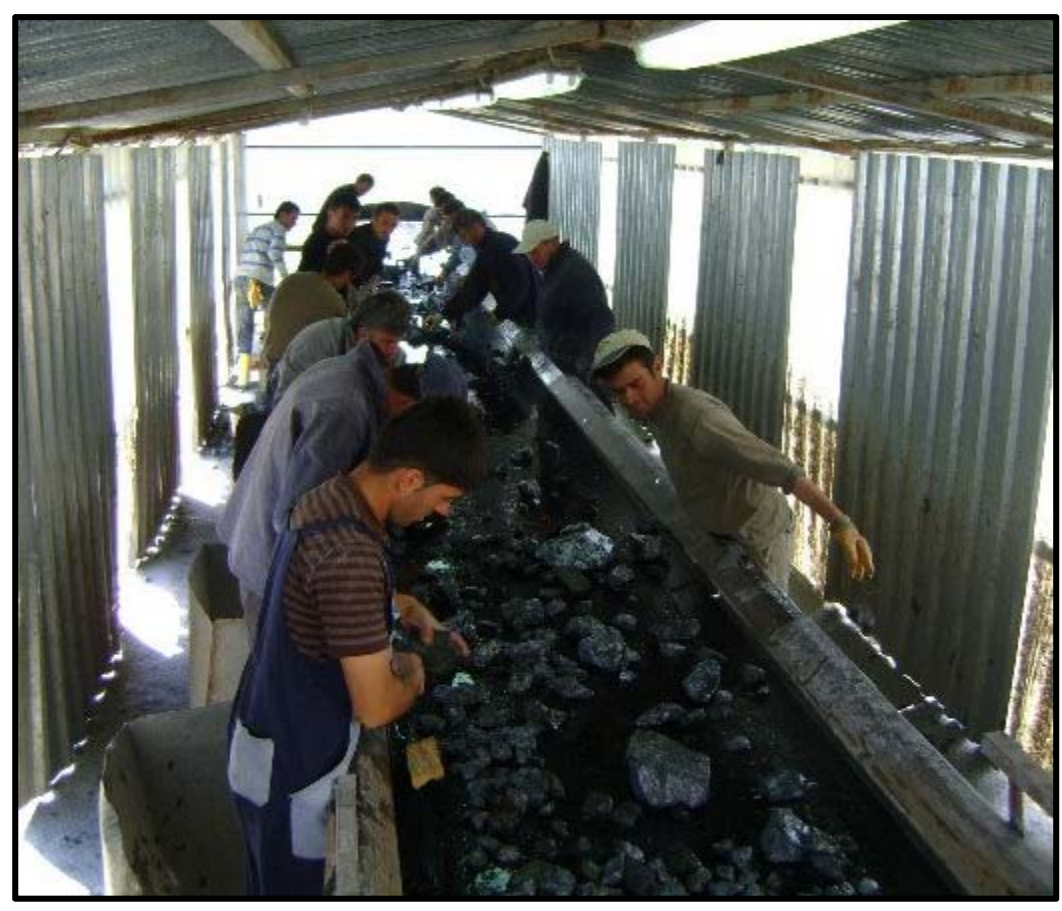

Fotoğraf 4: Türkiye'deki En Yaygın Zenginleştirme Yöntemi El ile Aylklama / Triyaj 
Türkiye'de krom yatakları Alpin tipi olup genellikle düzensiz dış şekilli, masif ve bantlı yapılar gösteren yataklar şeklindedir. İlk defa 1848 yılında Amerikalı Kimyager ve Akademisyen John Lawrence Smith (1818 - 1883) tarafindan Bursa'nın Harmancık Kayabaşı yöresinde bulunmuştur ${ }^{4}$. Yüksek tenörlü bu yataklar 1868 'de işletilmeye başlanmıştır (Zeytinoğlu, 1970; 267; Karahan, Özkan, 2011; 17). Harmancık’ta başlayan krom madenciliği 1927 yılında Fethiye ve 1936'da Guleman (Alacakaya) yöresinde devam etmiş, ilerleyen yıllarda Eskişehir, Hatay, Aladağ (Adana), Kayseri ve Erzincan'daki yataklar işletilmiştir.

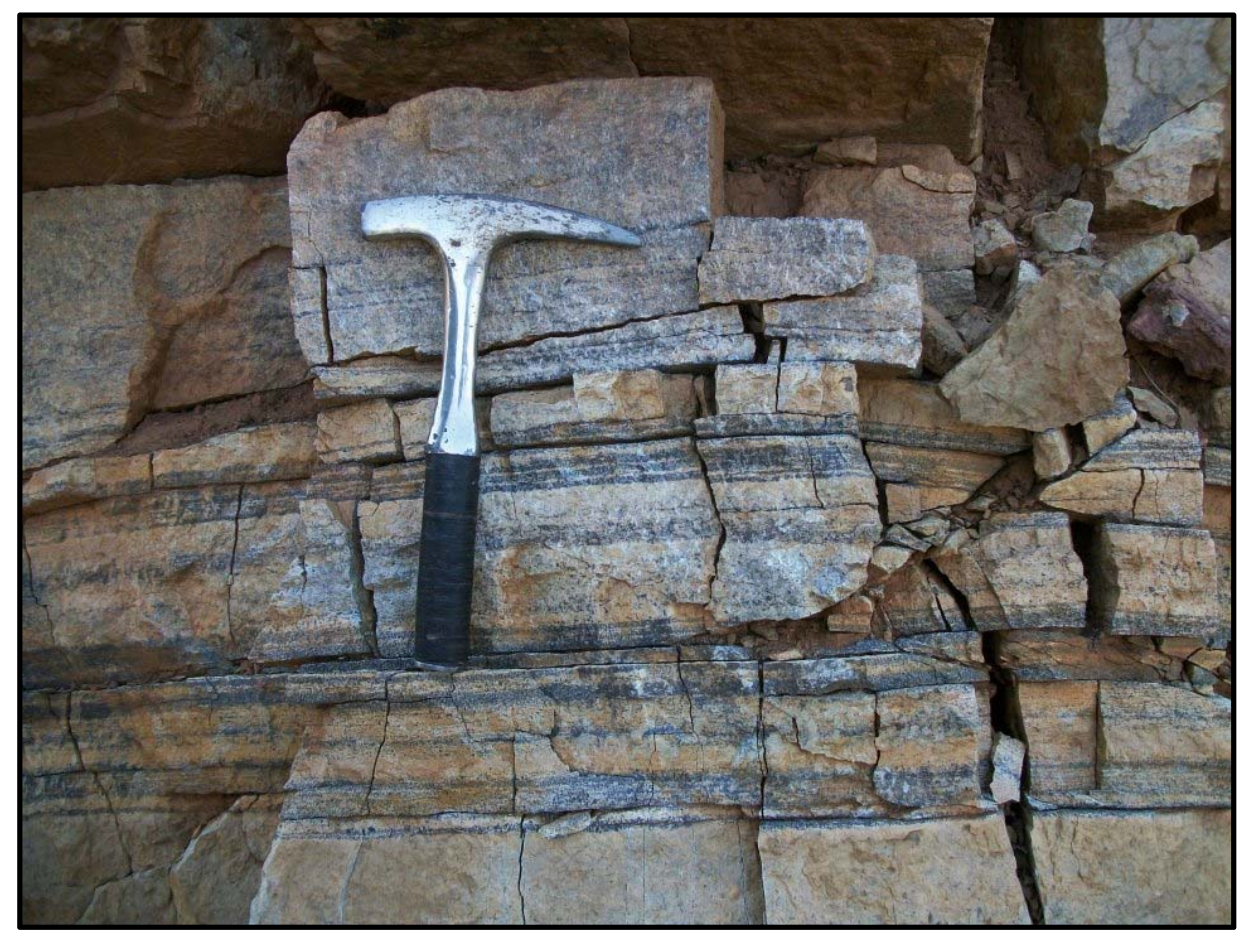

Fotoğraf 5: Bantlı Yapıdaki Kromit Yapılaşması Örneği (Bursa)

Türkiye krom madenciliği başlangıçta Fethiye, Muğla, Denizli gibi sahil şeridi ve limanlara yakın yüksek tenörlü yataklar üzerinde yoğunlaşmıştır. Genellikle yatağın üst kısmı açık olarak üretime başlanmış, derin kısımları ise bırakılmıştır. 1950'lerden sonra açık işletilebilir yatakların sayısı azaldıkça ileri aşamalarda yeraltı madenciliğine ve düşük tenörlü (\% $20-40$ $\mathrm{Cr}_{2} \mathrm{O}_{3}$ ) cevherlerin işletilmesine yönelinmiştir.

Yatağın boyutu ve topografyaya bağlı olarak kromit, açık veya yeraltı işletme yöntemi ile çıkartılır. Örneğin; Türkiye'de Batı Kef (Elazığ)'te açık işletme yöntemi ile başlanmış sonra yeraltı işletmesine dönüşmüştür. Günümüzde açık ve kapalı işletmelerin yanında çok sayıda her iki tipte de maden çıkarımı yapan işletme söz konusudur. Büyüklükleri açısından da Türkiye'de tespit edilen 37 yataktan sadece 15 tanesi büyük yatak $(200.000-500.000$ ton arası) kategorisinde değerlendirilebilmektedir.

\footnotetext{
${ }^{4}$ John Lawrence Smith'in Türkiye'deki çalışmaları ve krom konusundaki araştırmaları hakkında daha detaylı bilgi için Benjamin Silliman tarafından hazırlanan, Memoir isimli araştırmacının hayatı ve eserlerini konu alan çalışmaya bakılabilir. Eser için bkz. http://www.nasonline.org/publications/biographical-memoirs/memoir-pdfs/smith-j-lawrence.pdf
} 


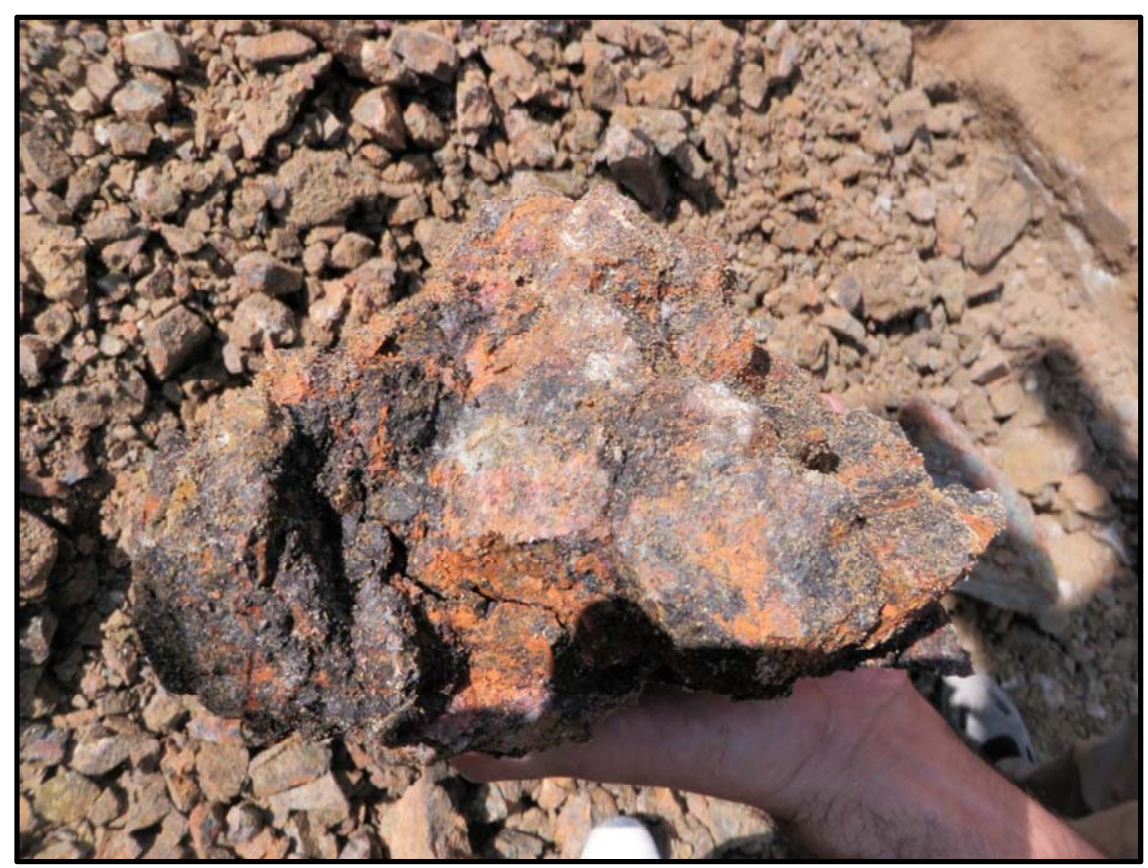

Fotoğraf 6: İşlenmeye Hazır Ham Krom Cevheri

\section{Türkiye Krom Rezervleri}

Günümüzde dünya toplam krom rezervi 7.9 milyar ton (7.959.400.000) olarak hesaplanmış, bunun da 1.6 milyar tonu görünür rezervdir. Dünyada bilinen en büyük görünür krom rezervleri Güney Afrika Cum. - Transvaal'de olup toplam rezervlerin \% 75'i bu ülkeye aittir. Zimbabve'de kromit rezervleri zengin ülkeler arasında önemli bir yer işgal etmektedir. Bu iki ülke dünyanın görünür krom rezervlerinin \% 80'ini ihtiva etmektedir. Güney Afrika Cumhuriyeti ve Zimbabve'nin dışında 27 ülkede daha kromit yatakları bulunmakta, söz konusu ülkelerin başında da Kazakistan, Arnavutluk, A.B.D., Japonya, Finlandiya, Türkiye, Kanada, İspanya, Yunanistan, İran, Pakistan ve Filipinler bulunmaktadır. Günümüz bilinen kromit rezervleri ve krom tüketim oranı hesaplandığında 100 yıl yetebileceği öngörülmektedir. Geçmişte olduğu gibi günümüzde de en büyük tüketiciler A.B.D. başta olmak üzere Almanya, Fransa, Birleşik Krallık ve Japonya gibi sanayileşmiş ülkelerdir. Avrupa kıtası özellikle de Almanya ve İsveç büyük ölçüde dışa bağımlıdır.

Türkiye'de krom yatakları belirgin bir dağılış düzeni göstermeksizin ultrabazik kayaçlar içinde ülke geneline yayılmış durumdadır. Yapılan çalışmalar Türkiye'de ofiyolitlerin kapladığı alanların yaklaşık $20.000 \mathrm{~km}^{2}$ olduğunu göstermiştir. Bunun da \% 63'ünü peridoditlerin oluşturduğu saptanmıştır (Karahan, Özkan, 2011; 20). Buna göre Türkiye'de krom yataklarının oluşumuna elverişli alanlar $12.600 \mathrm{~km}^{2}$ olarak tahmin edilmektedir. Günümüzde ise 800 kadar tek veya grup halinde krom yatağ1 ve krom cevheri zuhuru bilinmektedir.

Türkiye'de Güney Afrika Cumhuriyeti gibi zengin krom yatakları bulunmamakta ancak mevcut krom yatakları $\mathrm{Cr}$ ve Fe oranları nedeniyle Güney Afrika Cum. kromlarından daha kıymetlidir. Bununla birlikte Türkiye'de krom rezervlerine ait bilgiler çok sınırlıdır. Mevcut bilgilerin çoğu MTA’ya, bir kısmı da Etibank'a ait olup rezerv bilgilerinin önemli bir bölümü de çok yeni olmayıp 1980'lerde yapılıış çalışmalara dayanmaktadır. 
Ülkemizin görünür krom cevheri 20.179.000 ton olup bu miktar dünya rezervinin \% 1.26'sına karşılık gelmektedir. MTA Genel Müdürlügü̈nün verilerine göre 137 yatakta saptanan kaynaklar toplam 241.341.000 ton dolayındadır. Bunun \% 83'ü \% $10 \mathrm{Cr}_{2} \mathrm{O}_{3}$ 'den düşüktür. Bilinen rezervin sadece \% 5'i (13.087.000 ton) doğrudan satılabilir tenördür, \% 12'si de \% 10 - 35 arasında ve \% 35'ten fazladır. Zenginleştirilmesi gereken düşük tenörlü $\left(\% 10 \mathrm{Cr}_{2} \mathrm{O}_{3}\right.$ ' den az) yatakların envanteri çıkartılmamış ve potansiyel ortaya konmamıştır. Türkiye'de keşfedilebilir düşük tenörlü kromitler konusunda hala kapsamlı bir çalışma mevcut değildir. Bununla birlikte küçük ölçekli lokal çalışmalar 1şığında keşfedilebilir düşük tenörlü yataklarımızın 2 milyar tonu bulabileceği ifade edilmektedir (Karahan, Özkan, 2011; 56).

Türkiye'de düşük tenörlü krom kaynakları rezervinin çok daha büyük rakamlara çıkabileceğinin anlaşılmasının ardından bu alandaki çalışmalara hız verilmiştir. Düşük tenörlü kromit yatakları yönünden en iyi aranan Aladağ ofiyolitinde (Adana - Aladă̆ ilçesinin sınırları içindeki Karsantı, Kızılyüksel, Yataardıç, Kovanköy yöreleri) \% $5-6 \mathrm{Cr}_{2} \mathrm{O}_{3}$ tenörlü toplam 231.250.000 ton rezerv belirlenmiştir. Hatta yapılacak aramalarla daha önce çok iyi aranmayan bölgede bilinen kaynakların en az iki katına çıkabileceği tahmin edilmektedir. Ayrıca yakın yıllarda Köyceğiz - Kazandere, Fethiye - Ayı̈len, Kargacık ve Oyluk yörelerinde çok zengin yataklar bulunmuştur. Bunlarda hesaba katılırsa Türkiye'nin kromit cevheri bakımından bilinenden daha zengin olduğu anlaşılmaktadır.

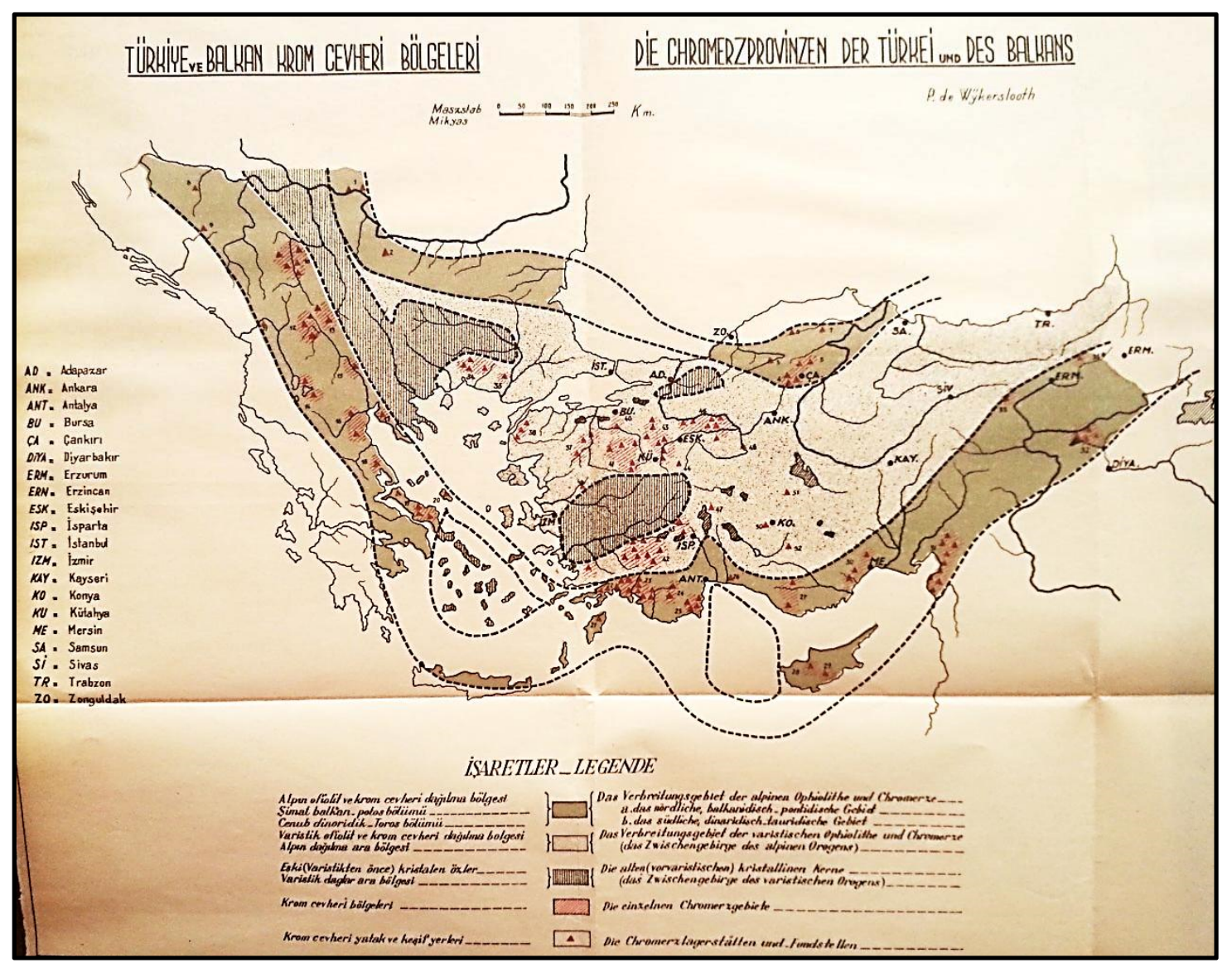

Şekil 1: Wijkersloot'un 1942'de Yayınlanan Türkiye Ofiolit ve Krom Sahalarını Gösterir Haritası

Türkiye'de krom yataklarının dağılımı ile ilgili ilk detaylı çalışmalardan biri Wijkerslooth (1942)'a aittir (Şekil 1). Araştırmacı hazırlamış olduğu haritada Alpin ofiolit sahasının 
yayılımını (Gri ile gösterilen alan) ile özellikle bugünküne çok benzer bir sonuçla Batı Anadolu'daki krom sahalarını tespit etmiştir. Bununla birlikte araştırmacı Çankırı, Elazı̆̆, Hatay ve Adana ile birlikte Kıbrıs'ın ve Balkanlar'ın krom sahalarını da göstermiştir (Kırmızı ile gösterilen alan).

Bilinen rezervlerimizin illere göre detaylı bir dağılımını ele almadan önce Türkiye'nin belli başlı Krom Bölgelerinden bahsetmek yerinde olacaktır. Yapılan arama çalışmaları neticesinde Türkiye'de 6 büyük krom sahası belirlenmiş olup bunlar ilk olarak şekil 2'de gösterildiği gibi sınırlandırılmıştır. Bahsi geçen bu 6 Bölge;

1. Eskişehir - Bursa Bölgesi

2. Sivas - Erzincan Bölgesi

3. Elazı ̆̆ Bölgesi

4. Gaziantep - Kahramanmaraş Bölgesi

5. Adana - Kayseri Bölgesi

6. Muğla Bölgesi

olarak belirlenmiştir.

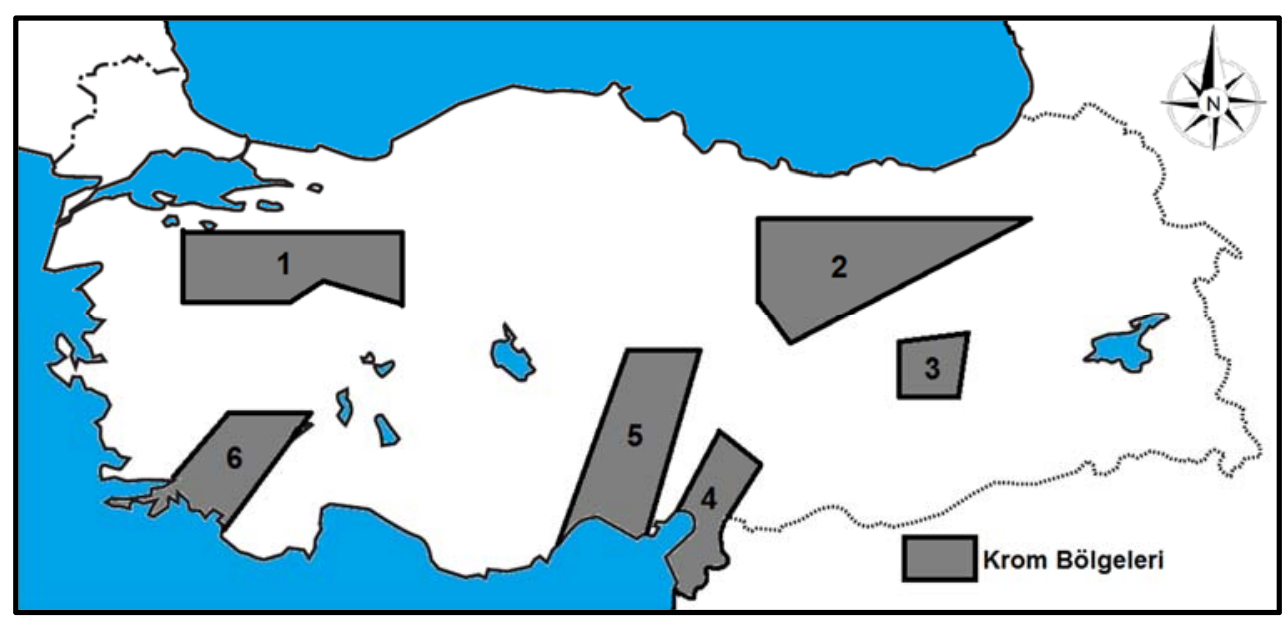

Şekil 2: Türkiye'nin Krom Bölgeleri

Engin $(1986 ; 21)$ 'e göre tespit edilen bu krom bölgelerinden önce Türkiye krom varlığ 8 mıntıkada toplanmıştı. İlerleyen yıllarda 6 Krom Bölgesi yapılan çalışmalar ışığında daha da netlik kazanarak şekil 3'te gösterildiği gibi yeniden düzenlenmiştir. Daha önce bölgeler belirlenirken sınırlı sayıdaki verilerden hareket edilmiş olmakla beraber ilerleyen yıllarda güncellenen krom bölgeleri rezervlerine göre 1'den 6'ya doğru sıralanmıştır. Buna göre;

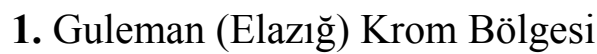

2. Fethiye - Köyceğiz - Denizli Krom Bölgesi

3. Bursa - Kütahya - Eskişehir Krom Bölgesi

4. Mersin - Adana (Karsantı) - Kayseri Krom Bölgesi

5. Sivas - Erzincan - Kopdăg Krom Bölgesi

6. İskenderun - Kahramanmaraş Krom Bölgesi olmak üzere krom sahaları sinırlandırılmıştır.

Burada dikkat çekilmesi gereken önemli bir husus son çalışmalarla Türkiye'nin en zengin krom sahasının 200 milyon tonu aşan toplam rezervi ile Adana ve buna bağlı olarak Mersin Adana - Kayseri Krom Bölgesi olması gerekse de çalışmalar devam etmekte olup henüz söz 
konusu buluşlar resmi kayıtlara geçmemiştir. Bu nedenle çalışmalarda hala Elazı ̆ / Guleman Krom Bölgesi en zengin bölge olarak gösterilmekte ve bilinen toplam krom rezervinin \% 45 'ine sahip bulunmaktadır.

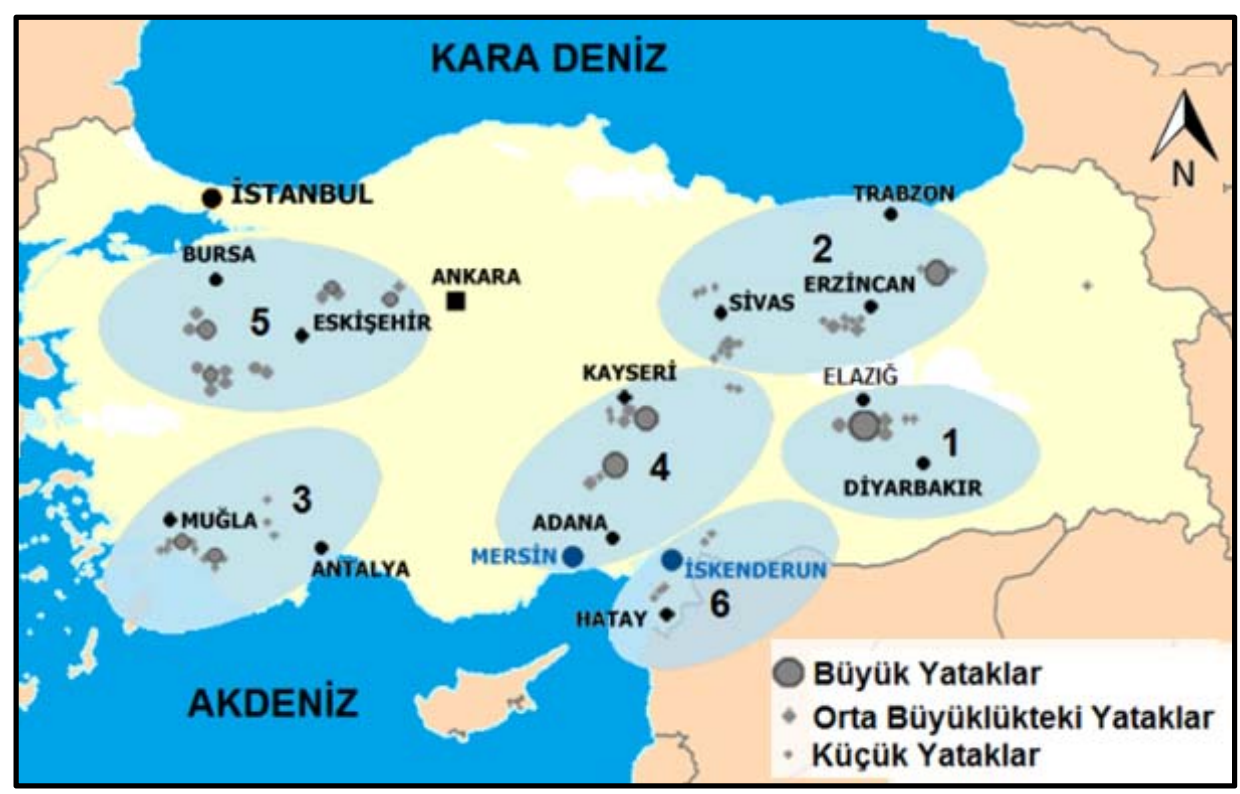

Şekil 3: Türkiye’nin Güncel 6 Krom Bölgesi

Yatakların büyüklükleri açısından bakıldığında ise Türkiye'de rezervi 1 milyon tonun üzerinde olan 8 yatak bulunmaktadır. Bunlardan 4 tanesi Elazı̆̆'da, 2 tanesi Adana'da, geri kalanlardan biri Erzincan diğeri de Sivas’ta bulunmaktadır (Tablo 2).

\begin{tabular}{|l|l|c|c|}
\hline \multicolumn{1}{|c|}{ İl } & \multicolumn{1}{|c|}{ Krom Yată̆ı } & Toplam Rezerv & Tenör (\%) \\
\hline Adana & $\begin{array}{l}\text { Karsantı: Kızılyüksek- } \\
\text { Yataardıç }\end{array}$ & 191.910 .696 & 30 \\
\hline Adana & Aladağ: Gerdibi-Gertepe & 15.909 .350 & $2-5$ \\
\hline Elazı̆ & Maden: Batı Kef & 5.750 .000 & 33 \\
\hline Erzincan & Tercan: Doğu Ezan & 2.772 .000 & $38-54$ \\
\hline Sivas & $\begin{array}{l}\text { Kangal: Eskiköy-Karanlık } \\
\text { Dere }\end{array}$ & 2.322 .000 & $5-15$ \\
\hline Elazı̆ & Maden: Batı Kef & 1.025 .000 & - \\
\hline Elazı̆ & $\begin{array}{l}\text { Maden: Sori Uzundamar- } \\
1\end{array}$ & 1.022 .000 & $42-48$ \\
\hline Elazı̆ & Maden: Sori Yenilasır & 1.010 .000 & $42-48$ \\
\hline
\end{tabular}

Kaynak: MTA, 2014.

Tablo 2: Türkiye'nin Bir Milyon Tondan Fazla Rezervli Krom Yatakları

Bunlardan en büyüğü yakın yıllarda keşfedilen ve hala arama çalışmalarının devam ettiği Adana'nın Karsantı ilçesindeki Kızılyüksek - Yataardıç krom sahasıdır. İller ölçeğinde daha detaylı inceleyeceğimiz tablo 2'de gösterilen krom yataklarında çalışmalar hala kesinlik kazanmış olmayıp, tenörleri ve mümkün + muhtemel rezervleri ile ilgili de kesinleşmiş bilgiler söz konusu değildir. 
Kromit yataklarımızı illere göre daha detaylı incelersek bu bakımından en zengin olan Adana ilimizin bilinen kromit yatakları; Kızılyüksek - Yataardıç (191.910.696 ton), Gerdibi Gertepe (15.909.350 ton), Kovankaya (6.269.304 ton), Gerdibi - Sivişli (868.276 ton), Dorucalı (350.000 ton) ve Çanakpınarı (300.000 ton)'dır (DPT, 2001; 28). Geri kalan yatakların rezervi ise düşüktür. Adana'nın söz konusu kromit yataklarının tümü Karsantı ve Aladağ'da bulunmaktadır. Etibank tarafından yapılan çalışmalarla Aladağ'da 144.1 milyon tonu görünür olmak üzere 191.9 milyon ton rezerv tespit edilmiştir. Söz konusu bu değerle saha Türkiye'nin en büyük ve dünyanın sayılı yatakları arasında yer almaktadır. İlin toplam kromit rezervi değerlendirildiğinde tenör $\% 4$ ila \% 35 arasında değişiklik gösterir niteliktedir.

Araştırmaların devam ettiği Adana'nın ardından toplam krom rezervleri açısından illerimizin durumuna bakmaya devam edecek olursak bunlardan şekil 4'te gösterilen Elazı̆̆g, Erzincan, Bursa, Sivas, Kayseri ve Denizli'nin 1.000.000 tonun üzerinde krom rezervi söz konusudur. Toplam rezervi bakımından Elazığ ilk sırada (11.828.000 ton) yer almakta olup geri kalan illerimizin 5 milyon tonun altında rezervleri söz konusudur. Toplam rezerv açısından Kütahya (537.700 ton) ve Muğla (484.857 ton)'dan sonra geri kalan illerimizin rezervi 300.000 tonu bulmamaktadir.

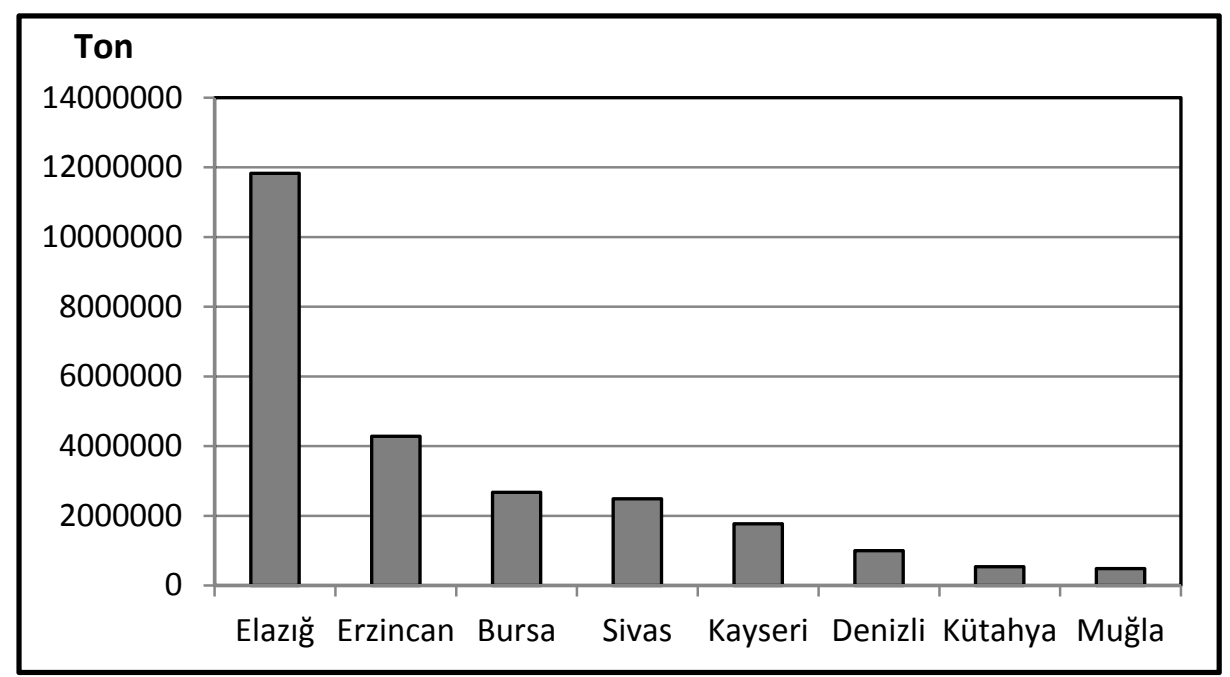

Kaynak: DPT, 2001.

Şekil 4: Türkiye'nin Toplam Rezervi Açısından Öne Çıkan İllerinin Krom Miktarı

Türkiye'nin rezervi en önemli yörelerinden biri Elazı̆̆'ın Maden ve Palu ilçelerindeki kromit yataklarıdır. İlçe sınırları içinde 20'den fazla kromit yatağı tespit edilmiştir. Bunlardan Batı Doğu Kef, Sori, Uzundamar I - II, Ayıdamar, Taşbaşı ve Kapın uzun yıllardır işletilmektedir. İlk olarak 1915 yılında keşfedilen yataklar ulaşım koşullarının elverişsiz olması nedeniyle işletilememiş, Fevzipaşa - Malatya - Diyarbakır demiryolu tamamlandıktan sonra Etibank Şark Kromları İşletmesi, Guleman (Alacakaya)'da kurulduktan sonra Sori Dağı kesiminde 1936'da işletilmeye başlanmıştır (30.000 ton). Nitekim Etibank'ın kurulmasıyla ele alınan ilk husus Elazığ kromları olmuştur. Önceleri açık işletme halindeyken zamanla kapalı işletmeye geçilerek $40 \mathrm{~m}$. derinliğe inilmiştir. Günümüzde sahada hem açık hem de kapalı işletme usulüyle üretim yapılmaktadır.

Türkiye'de görünür 20 milyon ton olan (\% $20 \mathrm{Cr}_{2} \mathrm{O}_{3}$ üzeri) krom potansiyelinin \% 45'lik bölümü Guleman yöresinde bulunmaktadır. Guleman yöresi krom potansiyeli ve üretimi açısından birinci derecede önemli sahamızdır. Günümüzde sadece Kapın'da açık işletme yapılmaktadır. Ayrıca ferrokrom tesislerinden biri de Guleman'da yer almaktadır. Söz konusu 
tesis 1977 'de Japonya'dan temin edilen kredi ve teknoloji ile 50.000 ton/y1l kapasiteyle üretime başlamıştır.

İlde 1986 - 1989 yılları arasında yapılan çalışmalar neticesinde kromit yataklarının Maden ve Palu ilçelerinde toplandığı anlaşılmaktadır. İl içindeki en önemli yataklar sırasıyla; Maden Bat1 Kef (5.750.000 ton), Batı Kef (1.025.000 ton), Sori - Uzundamar I. (1.022.000 ton), Sori - Yenilasir (1.010.000 ton), Maden - Kapın (700.000 ton), Maden - Doğu Kef (495.000 ton), Palu - Birek Tepe (460.000 ton), Maden - Kapın (300.000 ton), Maden - Cordik (290.000 ton) ve Maden - Uzundamar II. (280.000 ton)'dir (DPT, 2001; 31). Elazığ'da sayılan yatakların dışında 10 tane daha kromit yatağı bulunmakta olup bunların rezervi düşüktür.

Erzincan'da da 1981 - 1989 yılları arasında toplam 10 kromit yatağı tespit edilmiştir. Erzincan yatak sayısı bakımından 5. sırada (10 yatak), toplam rezerv açısından da 3. sırada yer almaktadır. Erzincan ile birlikte ilk üç ilimiz (Adana ve Elazığ) Türkiye toplam krom rezervinin \% 95.9'unu teşkil etmektedir. Erzincan rezervlerinin çoğu Tercan ilçesinde bulunmakta olup Doğu Ezan (2.772.000 ton), Kopdağ'ının Erzincan ili sınırları içindeki Karaçeşme (690.000 ton) ve Tercan - Siçankale (631.000 ton) yöresinde bulunmaktadır (DPT, 2001; 33). Geri kalan yatakların rezervi ise 100.000 tonun altındadır. Kopdağ, Türkiye'nin sayılı kromit yatakları arasında yer almaktadır. Tercan ilçesinde Coşan Ocak, Eren, Refahiye, Üzümlü ve Çayırlı yörelerinde irili ufaklı yüksek tenörlü yataklar bulunmaktadır. Guleman (Elazığg)'dan sonra ikinci önemli bölge olup 1950'li yıllardan buyana üretim yapılmakta ve 1981 - 1993 devresinde yılda ortalama 300.000 ton cevher üretilmiştir. Ayrıca ham cevher ihracatının terkedilmeye başlanması amacıyla Kopdağ'da 2009' da Çin sermayeli Kop Krom Madencilik Cevher Zenginleştirme Tesisi'nin temelleri atılmış, 2010'da da deneme üretimleri başlamıştır.

Zengin kromit yataklarının bulunduğu bir diğer ilimiz Bursa'dır. Bursa, aynı zamanda bu madenin ilk bulunduğu il olmakla beraber en fazla yatağa (25 yatak) sahip olan ilimizdir. Bugüne kadar 86 yatak işletmeye alınmış, çoğu değişik nedenlerle zaman içinde terkedilmiştir. Toplam 2.674.757 ton krom rezervine sahip olan ildeki belli başlı yatakların dağılımı; Orhaneli (1.000.000 ton), Harmancık/Miran - Hudut - Koca Ocak (470.000 ton), Büyük Orhan/Kırocak (277.000 ton), Büyük Orhan/Piribeyler - Kırocak (263.000 ton), Harmancık/Başalan Ocak (163.575 ton), Orhaneli/Ömeraltı - Kınalıbatak (111.207 ton) ve Harmanc1k/Delicegüney - Belece (100.000 ton) şeklindedir (DPT, 2001; 29). Geri kalan yatakların toplam rezervi ise 100.000 tonun altındadır. Tenör açısından ise ilde \% 10 ila 20 arasında değiştiği görülmektedir.

Orhaneli, Harmancık ve Büyükorhan çevrelerinde toplam 10 ocak işletilmektedir. Özellikle Orhaneli, Kırocak ve Büyük Orhan - Piribeyler rezervleri Türkiye'nin en önemli rezervlerindendir. Yöredeki yataklarda hem düşük hem de yüksek tenörlü (\% 40) toplam 5-6 milyon ton potansiyel rezervin varlığı tahmin edilmektedir.

Bursa'nın ardından 11 yatakta toplam 2.490.300 tonluk krom rezerviyle Sivas 5. sirada yer almaktadır. Sivas ili içinde ağırlıklı olarak Kangal, Divriği ve Zara ilçelerinde yer almakta olup toplam rezervin \% 97.5'i Kangal'da bulunmaktadır. En önemli yatak Kangal ilçesi sinırları içindeki Eskiköy - Karanlıkdere (2.322.000 ton) ve ilin toplam rezervinin \% 93.2'sine sahiptir (DPT, 2001; 35). 
MTA tarafından Kayseri ilinin 2 ilçesinde krom bulunmuş olup Pınarbaşı ilçesinde Dedeman 9 Numaralı Ocak (490.000 ton), Demircili (305.000 ton), Tarlaocak (294.000 ton), Kılıçmehmet (138.000 ton)'te ve Tomarza ilçesinde de Avşarsöğ̈̈tlü (250.000 ton)'de bulunur (DPT, 2001; 34).

Türkiye krom potansiyelinin yaklaşık \% 6'sını Muğla - Denizli arasındaki ofiyolit birimleri içinde bulunan kromit yatakları oluşturmaktadır. Bunlar ağırlıklı olarak Köyceğiz, Fethiye, Dalaman, Marmaris ve Ula ilçelerinde yer almakta ve Köyceğiz \% 37 tenörlü toplam 236.421 tonluk rezerviyle Muğla krom rezervinin yaklaşık yarısına (\% 48.7) sahiptir. Köyceğiz'in ardından Ula - Biticealan'da 102.000 ton ve Fethiye/Üzümlü - Sazlı'da 100.000 ton krom rezervi tespit edilmiştir (DPT, 2001; 35). Geri kalan yatakların özellikle de Dalaman'dakilerin rezervi 20.000 tonun altındadır. Geçmiş yıllarda Etibank yörede önemli miktarda üretim gerçekleştirmiş, özel sektöre devredilen yataklarda ise üretim devam etmektedir. Günümüzde Üçköprü, Kazandere ve Dilmen yataklarında üretim yapılmaktadır. Muğla ilinin üretim sahalarından elde edilen cevher uzun yıllar yurtdışına ihraç edilmiş, Antalya Ferrokrom Tesisi yapılınca ülke içinde işlenmeye başlanmıştır. Buradaki yataklar (Fethiye - Üçköprü sahası) 35 yıl boyunca Fransız sermayeli Fethiye Şirket-i Madeniyesi şirketince işletilmiş ve piyasa değerinin altında ihracat gerçekleştirmiştir. Kuruluş bu olumsuz gidişat nedeniyle 1964'te Etibank'a devredilmiştir.

Denizli'deki krom yataklarından Acıpayam, Tavas, Kale ve Beyağaç çevresindekiler işletilmiştir. $\mathrm{Bu}$ yataklardan Beyağaç/Karaismailler - Elmas Ocak 800.000 ton ve Acıpayam/Karaismailler - Aslan 103.500 Denizli'nin en büyük krom yataklarıdır (DPT, 2001; 30). Geri kalan beş yataktan rezervi en büyük olan 50.180 tonluk rezerviyle Acıpayam/Karanfilli'ye ait olup diğerleri ise önemsizdir.

Tokat'ın en önemli krom cevherleşmeleri Artova ilçesinde Salur Köyü civarında yer almaktadır. Köyün çevresinde birkaç yerde cevherleşme görülen yataklardan en önemlisi Tuztaşı Tepe Ocağı'dır. Geçmiş yıllarda yataktan açık ve kapalı işletme yöntemiyle üretim yapılmış, \% $10-48 \mathrm{Cr}_{2} \mathrm{O}_{3}$ tenörlü toplam 265.000 ton mümkün rezerv söz konusudur (DPT, $2001 ; 36)$.

Eskişehir genelinde 6 yatak da kromite rastlanmıştır. Sarıcakaya ve Merkez ilçelerine bağlı Gündüzler, Sepetçi, Margı ve Sazak yörelerinde \% 15 - 50 arasında değişen toplam 186.700 ton civarında rezerv varlığ süre işletilmiştir. Bugün Alpu/Yörük - Karacaören, Tekketepe - Başören - Türkmen, Alpu/Taştepe, Kurtuluş Ocak, Kısmet Ocak ve Ege Ocak’takiler işletilmektedir.

Erzurum ili Aşkale ilçesi Pırnakapan ve Saptıran köylerinde \% 5 - 48 tenörlü görünür + muhtemel toplam 35.500 ton rezervli cevher yatakları bulunmaktadır (DPT, 2001; 33). Bayburt ili rezervleri de Erzurum - Bayburt sınırları arasında kalan Kopdağ'ın Bayburt'a ait Kop Köyü (Bülent Ocak ve Engin Ocak) yakınındakiler olup bunlar işletilmektedir. İlin toplam muhtemel krom rezervi 114.130 tondur (DPT, 2001; 33).

Kahramanmaraş'ın Pazarcık ve Elbistan'da birkaç bin tonla sınırlı potansiyele sahip yataklar vardır. Pazarcık - Bolukçamtepe ve Balıkçılar gibi yatakların bir kısmı geçmiş yıllarda işletilmiştir. 
Yukarıda bahsedilenlerin dışında Kütahya ilinin Tavşanlı ilçesinin Madanlar - Dibecik mevkiinde 375.000 ton ve Malatya ilinin Darende ilçesinde Gülyılmaz - Çakır CO.'da 162.000 ton rezervli kromit yatağı bulunur (DPT, 2001; 35). Bunlara ilave olarak rezervi hakkında kesin bilgi söz konusu olmasa da Mersin ilinin de krom yatakları bakımından zengin olduğu söylenebilir. Krom yataklarının bir kısmı geçmişte işletilmiştir. Yataklar Merkez ve Erdemli ilçelerinde yoğunlaşmakta olup \% $10-48$ tenörlü 1.5 ila 2 milyon tonluk muhtemel + mümkün rezerve sahiptir. Gaziantep'te de çoğunlukla İslahiye ve Nurdağı ilçelerinde rastlanmakla birlikte rezervleri azdır (18.226 ton görünür). Yüzeyde olanların çoğunda geçmiş yıllarda üretim yapılmıştır.

\section{Dünya ve Türkiye'de Krom Üretimi}

Dünya krom üretimi ülkelerin ekonomik durumu ve çelik talebi ile doğrudan ilgilidir. $\mathrm{Bu}$ yüzden de yıldan yıla kromit çıkarımı ve krom üretimi değişmektedir. Ekonomik krizler, siyasi belirsizlikler, savaş durumundan kaynaklı politik ve iktisadi çalkantılar veya Çin gibi hızla büyüyen sanayi ülkelerinde yaşanan durum krom cevheri üretiminin dalgalanmasına neden olmaktadir.

\begin{tabular}{|l|c|c|c|c|c|}
\hline Ülkeler & $\mathbf{1 9 8 8}$ & $\mathbf{1 9 9 3}$ & $\mathbf{1 9 9 7}$ & $\mathbf{2 0 0 5}$ & $\mathbf{2 0 1 2}$ \\
\hline Güney Afrika Cum. & 4.244 .632 & 2.838 .044 & 6.162 .000 & 7.502 .762 & 11.310 .223 \\
\hline Kazakistan & $3.700 .000 *$ & 2.968 .200 & 1.798 .300 & 3.581 .242 & 5.233 .000 \\
\hline Hindistan & 820.863 & 1.064 .400 & 1.515 .286 & 3.714 .284 & 3.040 .000 \\
\hline Türkiye & $\mathbf{1 . 1 5 7 . 0 7 5}$ & $\mathbf{7 6 7 . 3 1 3}$ & $\mathbf{1 . 6 4 6 . 4 1 3}$ & $\mathbf{8 5 8 . 7 2 9}$ & $\mathbf{2 . 2 8 0 . 0 0 0}$ \\
\hline Umman & 4.000 & 10.236 & 17.985 & 34.000 & 554.800 \\
\hline Pakistan & 4.924 & 44.384 & 23.763 & 56.359 & 500.000 \\
\hline Avustralya & - & - & 18.756 & 90.260 & 452.300 \\
\hline Finlandiya & 536.309 & 516.457 & 588.856 & 572.000 & 452.000 \\
\hline Brezilya & 229.912 & 240.247 & 285.500 & 616.534 & 423.982 \\
\hline İran & 60.289 & 124.300 & 324.253 & 224.911 & 420.000 \\
\hline Rusya Fed. & $3.700 .000 *$ & 120.800 & 77.900 & 772.000 & 400.000 \\
\hline Arnavutluk & 1.109 .000 & 281.130 & 157.203 & 170.000 & 190.000 \\
\hline Zimbabve & 561.630 & 252.033 & 669.757 & 614.720 & 119.409 \\
\hline Madagaskar & 171.484 & 144.311 & 133.960 & 93.384 & 100.500 \\
\hline
\end{tabular}

*: 1988 için veri S.S.C.B.'ye ait olup Rusya ve Kazakistan için aynı değer gösterilmiştir.

Kaynak: British Geological Survey, 2014.

Tablo 3: Seçilmiş Yıllara Göre Ülkelerin Krom Üretim Miktarları (Ton)

Her ne kadar 2012'ye gelindiğinde toplam 21 ülkede krom üretimi gerçekleşmiş olsa da seçilmiş y1llara ait ülkelerin krom üretimlerinin gösterildiği tablo 3 'te kayda değer üretimleri olan ülkelere yer verilmiştir (Örneğin Küba ve Filipinler'in üretimleri çok düşük seviyelerdedir). Tüm yıllara ait veriler incelendiğinde Güney Afrika Cumhuriyeti, Kazakistan (Eski S.S.C.B.), Türkiye ve Hindistan dünya krom üretiminin çok büyük bir kısmını ellerinde bulundurmuşlardır. Söz konusu bu 4 ülke dünya krom üretiminin \% 84,7'sini karşılamakta olup sadece Güney Afrika Cumhuriyeti'nin payı \% 43.8 iken Türkiye'nin payı ise \% 8.83'tür (British Geological Survey, 2014).

1848 yılında bulunmasından 20 yıl sonra Türkiye'de krom madenciliği başlamıştır. Türkiye, başından itibaren krom üretici ülkeler arasında hep ilk sıralarda yer almıştır. 1900'lü yılların başına kadar dünya krom cevheri piyasasında tekel konumunda olmuş yılda birkaç bin tonu geçmeyen krom talebi hemen hemen tümüyle Türkiye tarafından karşılanmıştır. Hindistan ve 
Güney Afrika Cumhuriyeti'nde krom madenciliği başlayana (1906) kadar Türkiye'nin üretimdeki liderliği devam etmiştir. 1938 ve 1957 yıllarında tekrar liderliğe yükselmiş daha sonraları 3. ila 6. sıralarda kalmıştır. Örneğin; 1948 - 1952 yılları arasında ve 1955 - 1956 y1llarında krom üretiminde Türkiye dünya birincisi iken ilerleyen y1llarda gerilemiş, 1984'te de 4. olmuştur (Soykan, Mutluer, 1995; 44). Podiform yataklardan elde edilen yüksek kromlu cevherlerin metalürji sanayindeki üstünlüğünü kaybetmesiyle krom üreten ülkelerde önemli değişmeler meydana geldi. Türkiye önde gelen krom üreticisi olma durumundan uzaklaştı. Derin veya düşük tenörlü yataklardan daha yüksek maliyetle üretim yapmaya başladı.

\begin{tabular}{|c|c|c|c|c|c|}
\hline Yllar & Üretim (Ton) & Ylllar & Üretim (Ton) & Yıllar & Üretim (Ton) \\
\hline $\mathbf{1 8 9 7}$ & 11.550 & $\mathbf{1 9 0 6}$ & 32.650 & $\mathbf{1 9 1 4}$ & 9.830 \\
\hline $\mathbf{1 8 9 9}$ & 8.140 & $\mathbf{1 9 0 7}$ & 28.860 & $\mathbf{1 9 1 5}$ & $?$ \\
\hline $\mathbf{1 9 0 0}$ & 13.530 & $\mathbf{1 9 0 8}$ & 11.547 & $\mathbf{1 9 1 6}$ & $?$ \\
\hline $\mathbf{1 9 0 1}$ & 40.970 & $\mathbf{1 9 0 9}$ & 17.750 & $\mathbf{1 9 1 7}$ & 7.500 \\
\hline $\mathbf{1 9 0 2}$ & 34.620 & $\mathbf{1 9 1 0}$ & 17.030 & $\mathbf{1 9 1 8}$ & 1.000 \\
\hline $\mathbf{1 9 0 3}$ & 30.430 & $\mathbf{1 9 1 1}$ & 17.460 & $\mathbf{1 9 1 9}$ & 3.500 \\
\hline $\mathbf{1 9 0 4}$ & 19.170 & $\mathbf{1 9 1 2}$ & 20.090 & $\mathbf{1 9 2 0}$ & 25.000 \\
\hline $\mathbf{1 9 0 5}$ & 20.240 & $\mathbf{1 9 1 3}$ & 29.130 & $\mathbf{1 9 2 1}$ & $?$ \\
\hline
\end{tabular}

Kaynak: Eldem, 1970; 106 ve Enver, 1931; 5.

?: I. Dünya Savaşı'nın şiddetini artırdığı yıllarda ve Milli Mücadele'nin başlangıcında krom üretimi ile ilgili istatistiklere ulaşılamamıştır.

Tablo 4: Osmanlı İmparatorluğu Döneminde Anadolu Topraklarında Gerçekleşen Krom Üretimi

1924 'ten önceki üretimler ile ilgili olarak üretim miktarının aynı zamanda ihracat miktarını da ifade ettiğini söylemek yanlış olmaz. Nitekim Osmanlı İmparatorluğu'nun son yıllarıyla birlikte Türkiye Cumhuriyeti'nin ilk yıllarında yurtiçinde krom tüketimi söz konusu değildir. Osmanlı İmparatorluğu'nda bulunan kromun çıkartılıp işlenmesi ile ilgili o dönem yakın ilişki içerisinde olunan Almanya'dan birkaç firma bazı girişimlerde bulunmuşsa da I. Dünya Savaşı nedeniyle yarıda kalmıştır (Eldem, 1970; 105). Bununla birlikte yapmış olduğumuz arşiv çalışmaları ve Osmanlı İmparatorluğu'nun son dönemlerine ait iktisadi vesikalardan hareketle oluşturulan tablo 4'te 1897 - 1920 yılları arasında İmparatorluk sınırları içerisinde üretilen krom miktarları derlenmiştir. Günümüzdeki krom üretimine benzer bir durumun o dönemlerde de yaşandığı ve istikrarsız bir gelişimin olduğu gözlenmekle birlikte Balkan Savaşları ve I. Dünya Savaşı gibi büyük bunalımların olduğu yıllarda bunun beklenen bir durum olduğu aşikardır. Söz konusu dönemde toplam 400.000 ton civarında krom üretimi gerçekleşmiş, üretim 1901 'de en yüksek seviyesine çıkmış (40.970 ton) ve Cumhuriyet öncesi son üretim 25.000 ton olarak gerçekleşmiştir (Tablo 4). 1897'de dünya krom üretimi yaklaşık 30.000 ton olup Osmanlı İmparatorluğu bunun \% 38.5'ini, 1906' da da dünya geneli 100.000 tonluk krom üretiminin \% 32.6'sını sağlamıştır (Enver, 1931; 5). Ülke söz konusu bu üretim değerleriyle döneminin en büyük üreticisi ve krom pazarının belirleyicisi konumunda yer almaktayd.

Türkiye Cumhuriyeti'nin uzun dönemli krom cevheri üretimi incelendiğinde bazı dalgalanmalara karşılık genel bir artış görülmektedir. Genel olarak Türkiye krom üretimindeki istikrarsızlığı birkaç örnekle izah edecek olursak; 1953'te 912.523 ton olan üretim 1954'te 561.549 tona kadar gerilemiş, 1957 'deki 954.963 tonluk üretimi takiben hemen ertesi y1l 534.728 tona, 1959 'da da 397.865 tona kadar gerilemiştir (DPT, 2001; 20). Benzer bir diğer dikkat çekici dalgalanma 1990'lı yıllarda yaşanmış; 1992'de 1.066.814 tonluk üretimin 
ardından 1993 yılında üretimin 767.313 tona, yine 1999'da 1 milyonu aşan (1.019.542 ton) üretimin ardından 2000'de kabaca yarı yarıya bir azalmanın (545.725 ton) gerçekleşmesinde gözlenebilmektedir. $\mathrm{Bu}$ örneklerden ve sayısı artırılabilecek daha başka dalgalanma durumlarından ötürü krom üretim ve ticaretinde uluslararası pazar durumunu çok iyi bilmek ve bunun için stratejilerin geliştirilmesi sektörün sürdürülebilirliği ve sağlıklı bir büyüme içerisine girebilmesi açısından büyük önem taşımaktadır.

Krom üretimimiz 1925 'te 7.506 ton iken 1927 'ye gelindiğinde 18.300 tona çıkmıştır. II. Dünya Savaşı öncesinde dünyanın silahlanma yarışı ile ilgili olarak krom ihtiyacı artmış, bu durum Türkiye'nin çıkarımının da artmasına neden olmuş, 1935 yılında ilk defa 100.000 tonun üzerine (150.400 ton) çıkmıştır ${ }^{5}$. Üretim 1945 'ten sonra daha belirgin bir artış göstermiş ve 1950 'de 422.529 tona yükselmiştir (Şekil 5). Bununla birlikte özellikle 1975 sonrası dalgalanmalar daha belirgindir. Soğuk Savaş, silahlanma yarışı, artan refah seviyesi ve buna bağlı hemen her alanda hızla artan tüketim sanayinin temel hammaddelerinden krom üretimine de yansımıştır. 1970'lere kadar metalürji sanayinin (Paslanmaz çelik ve diğer çelik sanayileri) talebi sadece podiform tip yataklardan yüksek tenörlü ve yüksek $\mathrm{Cr} / \mathrm{Fe}$ oranlı cevherlerden karşılanmıştır. Stratiform tip yataklardan üretilen düşük $\mathrm{Cr} / \mathrm{Fe}$ oranlı olan yüksek demirli cevher ise daha çok kimya sanayinde kullanılmıştır. Çelik teknolojisindeki yenilikler sayesinde stratiform tipi yatakların yüksek demirli cevherlerinin metalürji sanayinde kullanımı mümkün hale gelince dünya krom rezervlerinin \% 90'ından fazlasını oluşturan stratiform tipi yataklardan yapılan krom cevheri üretimi artmaya başlamıştır. Türkiye gibi podiform yataklardan krom üreten ülkelerin konumlarında 1970'lerden sonra önemli değişmeler yaşanmıştır. Bu gelişmeler nedeniyle Türkiye önde gelen kromit üreticisi ülke durumundan uzaklaşmıştır. Bunda Türkiye krom madenciliğinin artık derin ve düşük tenörlü yataklardan gittikçe daha yüksek maliyetle üretim yapmasının da büyük payı olmuştur.

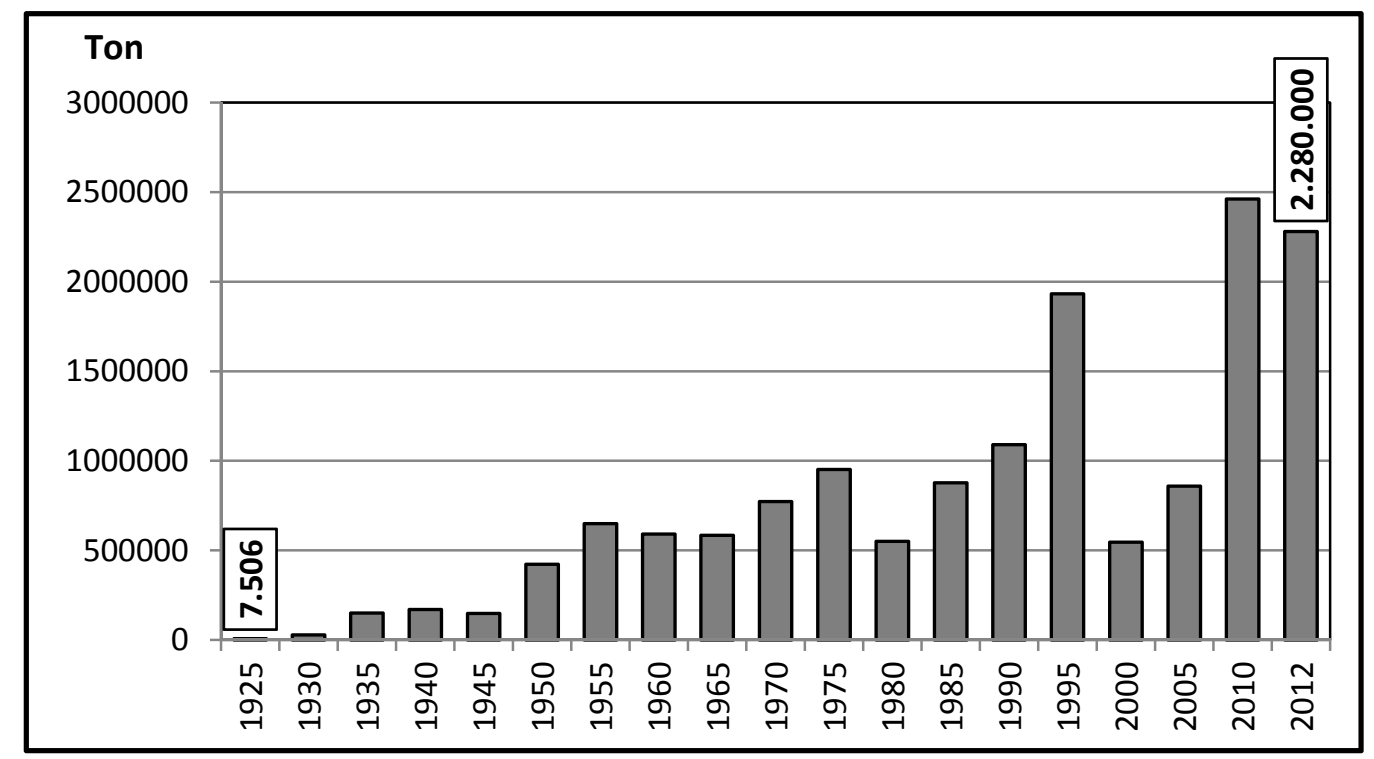

Kaynak: DPT, 2001; British Geological Survey, 2014.

Şekil 5: Türkiye'nin Yıllar İtibariyle Krom Üretim Miktarı (Tüvenan)

\footnotetext{
${ }^{5}$ Türkiye'nin II. Dünya Savaşı yıllarındaki krom üretim ve ticaretiyle ilgili daha detaylı bilgi için bkz. Nuri Karakaş, 2010, “İkinci Dünya Savaşı Yıllarında Türkiye’nin Krom Satışı ve Müttefik Politikaları”, Ege Üniversitesi Tarih İncelemeleri Dergisi, Cilt: XXV., Sayı: 2, s. $447-482$.
} 
Yukarıda sayılan olumsuzluklara rağmen giderek artan üretim 1980'de 550.719 tona düşmesinin ardından 1986 'da 1.000 .000 tonun üzerine (1.040.000 ton) çıkmıştır. 1995'te 2.080 .000 tona yükselmişse de 2000 yılından sonra özelleştirme nedeniyle 2005 'te 858.729 tona inmiş daha sonra yeniden yükselmeye başlamıştır. Son olarak krom üretimimiz 2012'ye gelindiğinde 2.280.000 ton olarak gerçekleşmiştir (Şekil 5). Türkiye 2012'deki söz konusu üretim değeriyle dünya sıralamasında 4. olmuş ve toplam krom üretiminin \% 8.83 'ünü sağlamıştır. Burada Türkiye'nin krom üretimiyle ilgili belirtilmesi gereken bir diğer önemli husus da hala Avrupa'nın en büyük üreticisi konumunda oluşu ve krom ihtiyacı yıldan yıla değişkenlik gösterse de büyük pazarlara yakınlığı ile krom ülkemiz için büyük avantajlar içeren bir madenimiz olmaya devam edecektir.

\begin{tabular}{|c|c|c|c|}
\hline Yıl & $\begin{array}{c}\text { Dünya } \\
\text { (Ton) }\end{array}$ & $\begin{array}{c}\text { Türkiye } \\
\text { (Ton) }\end{array}$ & $\begin{array}{c}\text { Türkiye Yüzdesi } \\
\text { (\%) }\end{array}$ \\
\hline $\mathbf{2 0 0 3}$ & 15.900 .000 & 229.294 & 1.44 \\
\hline $\mathbf{2 0 0 4}$ & 18.000 .000 & 506.421 & 2.81 \\
\hline $\mathbf{2 0 0 5}$ & 19.200 .000 & 858.729 & 4.47 \\
\hline $\mathbf{2 0 0 6}$ & 21.200 .000 & 1.059 .901 & 4.99 \\
\hline $\mathbf{2 0 0 7}$ & 24.000 .000 & 1.678 .932 & 6.99 \\
\hline $\mathbf{2 0 0 8}$ & 24.800 .000 & 1.885 .712 & 7.60 \\
\hline $\mathbf{2 0 0 9}$ & 20.100 .000 & 1.770 .029 & 8.80 \\
\hline $\mathbf{2 0 1 0}$ & 27.500 .000 & 2.461 .314 & 8.95 \\
\hline $\mathbf{2 0 1 1}$ & 26.500 .000 & 2.281 .981 & 8.61 \\
\hline $\mathbf{2 0 1 2}$ & 25.800 .000 & 2.280 .000 & 8.83 \\
\hline
\end{tabular}

Kaynak: British Geological Survey, 2014.

Tablo 5: Dünya Geneli ve Türkiye'nin Krom Cevheri (Tüvenan) ve Konsantresi Üretimi

Önceki bölümlerde de değinildiği üzere Türkiye dünya krom üretiminde başlangıçta çok daha büyük bir paya sahipken çeşitli faktörler nedeniyle bu oran yıldan yıla azalma göstermiştir. Bununla birlikte son on yılda Türkiye'nin dünya krom üretimindeki payında yeniden dikkat çekici bir artışın yaşandığı gözlenmektedir (Tablo 5). Son on y1lın en düşük değerinin gerçekleştiği 2003 yılının ardından 2010 yılına kadar düzenli bir artış eğilimine girilmiş ve Türkiye'nin payı \% 8.95'e yükselmiştir. Ertesi yıl küçük ölçekli bir gerileme yaşansa da yeniden yüzdelik payında bir artış yaşanmış olup son 4 yıl için \% 8'in altına inmemiştir (Tablo 5).

\section{Türkiye Krom Sektörü ve Ticareti}

Daha öncede belirtildiği gibi Türkiye, dünyanın sayılı krom ülkeleri arasında yer almakta ve bu alanda önemli gelir sağlamaktadır. Bununla birlikte henüz sanayileşmekte olan ülkemizin A.B.D. başta olmak üzere pek çok gelişmiş ülkenin de vurguladığı gibi stratejik bir kaynak olan kromu ham cevher olarak zaman zaman oluşan pazar şartlarından ötürü değerinin altında satması gerek kendi ekonomisi gerekse sanayisi için oldukça yıpratıcı bir durumdur. Nitekim kaliteli ve kolay çıkarılabilen yatakların çok büyük bir kısmının tükendiği düşünülecek olursa, artan nüfusu ve gelişmekte olan sanayisi için vazgeçilemeyecek bir değere sahip kromun üretimi ve işlenmesi üzerinde dikkatle durulması gerekmektedir. Bu noktada asıl vurgulanmak istenen kromun üretim teknolojileri, rezerv tespitleri, çevreyle uyumlu sürdürülebilir bir faaliyet halini alması ve işlenmesi gibi noktalar ne kadar elzem ise krom politikaları, pazar araştırmaları ve sektörün bir bütün olarak önemi de üzerinde durulması gereken en önemli noktaların belki de ilkini oluşturmaktadır. Nitekim dünyada örneklerini gördüğümüz bir 
dönemin krom üreticisi ülkelerinin ilerleyen yıllarda krom ithalatı edecek pozisyona gelmeleri plansız bir yaklaşımla Türkiye'nin de başına gelebilir.

Türkiye yıllardır ürettiği kromun tamamını dış pazarlara sunmuştur. Kimi zaman ekonomik bunalımlar ve savaş şartları nedeniyle beklediği kazancı sağlayamamış ve sektör ekonomik zorluklarla karşılaşmıştır. İyi kalitede ve ulaşım imkânlarının elverişli olduğu çoğu yatağın büyük ölçüde ekonomik özelliğini yitirdiği ya da tükendiği göz önüne alındığında ülkemiz için krom üretim maliyetinin de buna bağlı olarak artması doğal bir sonuçtur. Önceleri tamamıyla yurtdışına endeksli krom üretimimiz gelişen ülke sanayisiyle birlikte yurtiçinde de aranır hale gelmiştir ${ }^{6}$. Günümüzde Türkiye kendi krom ihtiyacını her ne kadar rahatlıkla karşılayabilir düzeyde olsa da krom gibi tükenebilir bir kaynağın ilerleyen yıllarda maliyet artışına bağlı olarak ve rezervlerin azalmasıyla birlikte daha az ve daha pahalı olacağı şüphesizdir. Öte yandan günümüzde Türkiye'nin krom işleme ve diğer krom ürünleri (Krom konsantresi ve kimyasalları gibi) üretim tesisleri hala çok sınırlı olup bu alanda faaliyet gösteren sadece birkaç firmadan bahsedilebilmektedir.

Türkiye'de krom üretimi ve işleme konusunda faaliyet gösteren tesislerin gösterildiği tablo 6 'da da anlaşıldığ üzere bahsi geçen işletmelerin toplam kapasitesi gelişmekte olan bir ülke için özellikle de krom gibi sanayinin temel hammaddelerinden biri için oldukça düşük düzeydedir. Türkiye'nin hızla ham cevher ihracatından uzaklaşıp işlenmiş krom ve krom ürünleri ihracatına geçmesi sektör için büyük önem taşımaktadır. Bununla birlikte Türkiye'deki krom işleme ve krom ürünleri üretimiyle ilgili tesislerin gösterildiği ilgili tablo her ne kadar olumlu bir gelişme ortaya koysa da hala yetersiz bir seviyede olunduğunu göstermektedir. Nitekim yıllık krom üretimimiz göz önüne alındığında bahsi geçen tesisler tam kapasite çalışsa dahi işleyemeyecek düzeyde olduğu anlaşılmaktadır.

\begin{tabular}{|c|c|c|c|c|}
\hline 11 & Yer & $\begin{array}{c}\text { Üretim } \\
\text { Konusu } \\
\end{array}$ & $\begin{array}{c}\text { Kapasite } \\
\text { (Ton) }\end{array}$ & $\begin{array}{c}\text { İstihdam } \\
\text { (Kiși) }\end{array}$ \\
\hline Dedeman Madencilik & $\begin{array}{l}\text { Kayseri- } \\
\text { Eskişehir }\end{array}$ & $\begin{array}{c}\text { Krom Cevheri } \\
\text { ve Konsantresi }\end{array}$ & 525.000 & \multirow{2}{*}{385} \\
\hline Dedeman Madencilik & Pozantı ve Aladağ & $\begin{array}{l}\text { Krom Atığı } \\
\text { (Şlam) }\end{array}$ & 10.000 & \\
\hline Bilfer Madencilik ve Tur. A.Ş. & $\begin{array}{c}\text { Kangal - Darende } \\
\text { - Hafik }\end{array}$ & Krom Cevheri & 210.000 & \multirow[b]{2}{*}{225} \\
\hline Bilfer Madencilik ve Tur. A.Ş. & $\begin{array}{c}\text { Kangal - } \\
\text { Kuluncak - } \\
\text { İskenderun }\end{array}$ & $\begin{array}{c}\text { Krom } \\
\text { Konsantresi }\end{array}$ & 119.000 & \\
\hline Aksu Madencilik ve Sanayi A.Ş. & $\begin{array}{l}\text { Pınarbaşı - } \\
\text { Tomarza }\end{array}$ & $\begin{array}{c}\text { Krom } \\
\text { Konsantresi }\end{array}$ & 100.000 & 200 \\
\hline Eti Elektrometalürji A.Ş. & Fethiye & Krom Cevheri & 100.000 & \multirow[b]{3}{*}{ ? } \\
\hline Eti Elektrometalürji A.Ş. & Fethiye & Silikoferrokrom & 8.000 & \\
\hline Eti Elektrometalürji A.Ş. & Fethiye & $\begin{array}{c}\text { Yüksek } \\
\text { Karbonlu } \\
\text { Ferrokrom }\end{array}$ & 10.000 & \\
\hline TOPLAM & & & 1.082 .000 & \\
\hline
\end{tabular}

Tablo 6: Türkiye'nin Başlıca Krom ve Krom Ürünleri Tesisleri

\footnotetext{
${ }^{6}$ Günümüz itibariyle yurtiçi krom tüketimi kurulu tesislerin tam kapasite çalışmaları durumunda yıllık 500.000 ton civarındadır.
} 
Türkiye krom sektöründen bahsederken bu alanda kendi ihtiyacımızı tam anlamıla karşılayamadığımız gibi çoğu krom ürününde de büyük oranlarda ithalatımızın söz konusu olduğunu belirtmek gerekir. Türkiye gibi geçmişten beri krom sektöründe söz sahibi olan bir ülkenin ağırlıklı olarak üret ve sat anlayışıyla hareket etmesi döviz kaybı yanında ilerleyen yıllarda bu hususta da dışa bağımlı olmamıza zemin hazırlamaktadır. Bu durumu krom ve zenginleştirilmiş krom cevheri ithalat durumumuzu gösterir şekil 6'da da görmek mümkündür. Genel olarak dünya krom cevheri ticaretinde görülen dalgalanmalar Türkiye'nin ithalat durumunda da gözlenebilmekle beraber özellikle son birkaç yılda genel bir artıştan bahsetmek mümkündür. İthalatımızda 2000 - 2005 yılları arasındaki büyük dalgalanmaların ardından nispeten daha düzenli bir artış eğilimi görülmektedir (Şekil 6). 2000'de toplam 69.469 tonluk ithalatın ardından 2005 'te 89.843 tona çıkmış hemen ertesi yıl küçük ölçekli bir gerilemenin ardından 2007 'de 100.000 tonu aşmış, 2011 'de 122.070 ton, 2012'de de 162.265 tonla son 13 yılın en yüksek ithalat seviyesine ulaşılmıştır (Şekil 6). Gelişmekte olan ülkemizde yıldan yıla artan krom ve krom ürünleri ihtiyacına bağlı olarak ithalatın da gerekli iç tedbirlerin alınmaması durumunda çok daha hızlı artacağı öngörülmektedir. 2012'ye gelindiğinde Türkiye, Güney Afrika Cumhuriyeti'nden 161.310 ton ile toplam ithalatının \% 99.4'ünü yani tamamını karşılamakta olup Hollanda'dan 910.9 ton, Birleşik Krallık'tan 34 ton ve Almanya'dan da 6 ton krom ve zenginleştirilmiş krom cevheri ithal etmiştir (TÜİK, 2014).

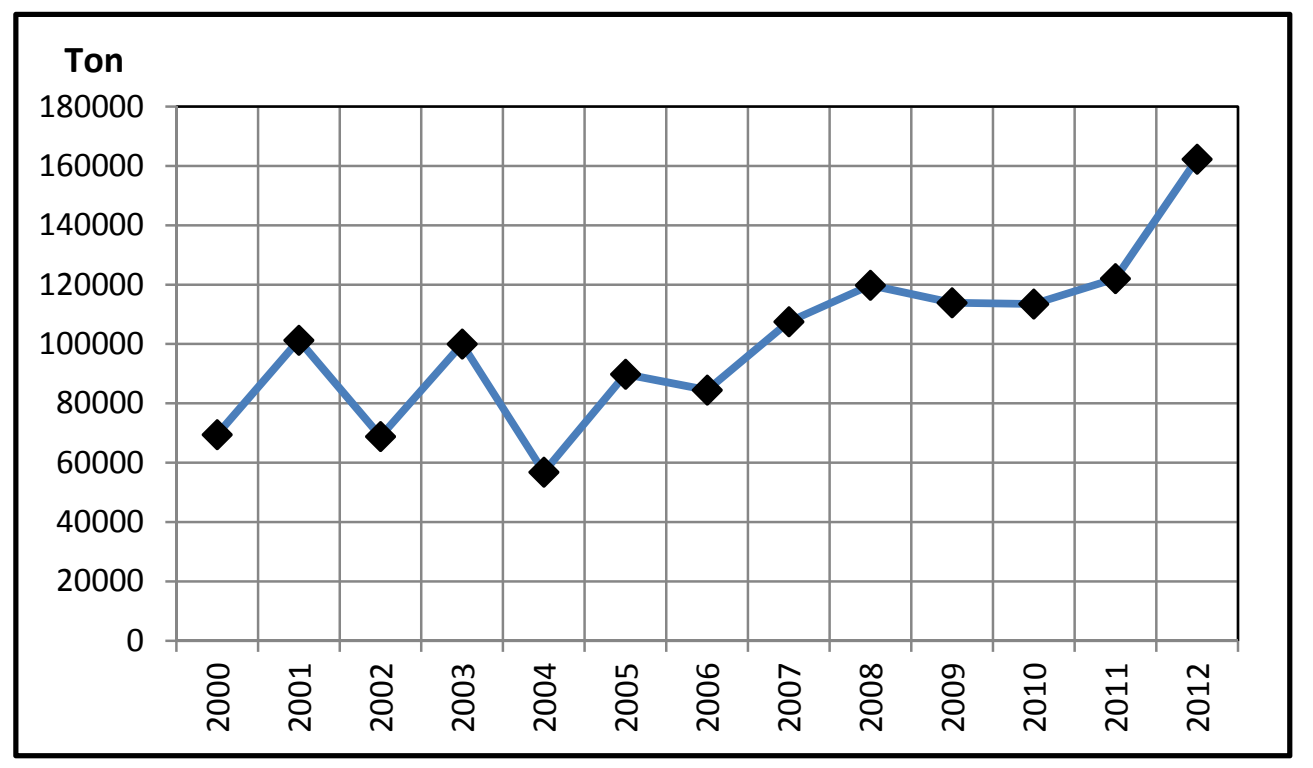

Kaynak: TÜIK, 2014.

Şekil 6: 2000 - 2012 Yılları Arasında Türkiye'nin Krom ve Zenginleştirilmiş Krom Cevheri İthalat Miktarı

Krom cevheri ihracatımız tümüyle dünyanın politik ve ekonomik durumuna, çelik ve refrakter sanayisindeki gelişmelere bağlıdır. Bu yüzden uzun vadeli anlaşmalar yapılmamakta, dünya paslanmaz çelik dolayısıyla ferrokrom fiyatları diğer ülkelerin fiyat ve ihtiyaç miktarlarına göre yıldan yıla önemli değişiklikler göstermektedir. Bu nedenle krom madenciliği dış pazarda oluşan fiyat dalgalanmalarından büyük ölçüde etkilenmektedir. Bu oynamalarda kimi ülkelerde yeni yatakların bulunmasının da etkisi vardır.

Uzun yıllar krom cevheri ihraç eden ülkelerin başında yer almasına rağmen doğrudan satılabilir sınırlı kaynakların hızla tükenmesi ve artan krom ihtiyacı yüzünden eskiden olduğu gibi yüksek tenörlü parça cevher üretimi ve satılması dönemi bitmiştir. Bu nedenle düşük tenörlü kromitlerin zenginleştirilmesine cevher işleme için büyük kapasiteli maden 
işletmelerine ve yüksek teknolojiyle çalışan zenginleştirme tesislerine ihtiyaç vardır. $\mathrm{Bu}$ amaçla 1962'de Antalya, 1978'de Elazı̆̆ Ferrokrom ve 1984'te Mersin Kromsan Krom Bileşikleri ve özel sektörün devreye girmesiyle yurt içinde işlenmeye başlanmış ham cevher yerine yarı mamul ürünlerin ihracatı gelişmiştir. Ancak bu çalışmaların yeterli olduğunu söylemek pek mümkün değildir. Zira mevcut tesislerde verim ve kapasite kullanımı düşük ve çoğu tesiste açığa giden cevher kaçağı \% 6'dan fazladır. Hatta bu kaçağın geçmişte bazı tesislerde \% $15 \mathrm{Cr}_{2} \mathrm{O}_{3}$ düzeyine kadar çıktığı bilinmektedir (Karahan, Özkan, 2011; 17). Bütün bu olumsuzluklara rağmen Türkiye krom cevheri, ferrokrom ve krom kimyasalları üretimi ihracata yönelik yapılmakta ve ferrokrom ihracatı da yıldan yıla artmaktadır.

Türkiye özellikle geçmişte dünya krom ticaretinde söz sahibi olan birkaç ülkeden biri olmuş hatta bazı yıllar krom ihracatında dünya birincisi olmuştur. İlerleyen yıllarda ekonomik işlerliğini yitirmiş yataklar ve artan maliyet yüzünden gerilese de gerek yurtiçinde üretilen madenlerin ihracatı konusunda gerekse uluslararası piyasalarda ihracatçı bir ülke olması noktasında Türkiye hala önemini korumaktadır. Son birkaç yıla baktığımızda 2007'de Türkiye $\%$ 12.8'lik krom ihracatı payıyla dünya genelinde 3. olmuştur. Yurtiçinde üretilen madenlerimiz içerisinde ihracat paylarına baktığımızda ise 2006 ' da \% 6, 2009' da \% 11, 2012 'de ise mermer (\% 45) ve bakırın (\% 11) ardından \% 10'luk payıyla en fazla ihraç edilen üçüncü madenimiz olmuştur (MİGEM, 2014).

\begin{tabular}{|c|c|c|c|}
\hline Yillar & $\begin{array}{c}\text { İhracat } \\
\text { (Ton) }\end{array}$ & Yillar & $\begin{array}{c}\text { İhracat } \\
\text { (Ton) }\end{array}$ \\
\hline $\mathbf{1 9 2 4}$ & 3.400 & $\mathbf{2 0 0 1}$ & 326.697 \\
\hline $\mathbf{1 9 2 5}$ & 7.506 & $\mathbf{2 0 0 2}$ & 284.296 \\
\hline $\mathbf{1 9 2 6}$ & 6.670 & $\mathbf{2 0 0 3}$ & 363.699 \\
\hline $\mathbf{1 9 2 7}$ & 18.318 & $\mathbf{2 0 0 4}$ & 575.030 \\
\hline $\mathbf{1 9 2 8}$ & 11.849 & $\mathbf{2 0 0 5}$ & 847.534 \\
\hline $\mathbf{1 9 2 9}$ & 16.178 & $\mathbf{2 0 0 6}$ & 1.079 .870 \\
\hline $\mathbf{1 9 3 0}$ & 25.945 & $\mathbf{2 0 0 7}$ & 1.382 .074 \\
\hline $\mathbf{1 9 3 5}$ & 155.140 & $\mathbf{2 0 0 8}$ & 1.816 .426 \\
\hline $\mathbf{1 9 4 0}$ & 123.049 & $\mathbf{2 0 0 9}$ & 1.745 .751 \\
\hline $\mathbf{1 9 6 5}$ & 424.226 & $\mathbf{2 0 1 0}$ & 2.257 .018 \\
\hline $\mathbf{1 9 9 5}$ & 1.531 .129 & $\mathbf{2 0 1 1}$ & 2.159 .841 \\
\hline $\mathbf{2 0 0 0}$ & 467.009 & $\mathbf{2 0 1 2}$ & 2.128 .704 \\
\hline
\end{tabular}

Tablo 7: Türkiye'nin Krom Cevheri ve Konsantresi İhracatı

Türkiye'nin y1llar itibariyle ihracat durumuna bakacak olursak burada dikkat çekilmesi gereken noktalardan biri Cumhuriyetimizin ilk yıllarından kabaca 1960'lara kadar üretim miktarının aynı zamanda yaklaşık olarak ihracat rakamlarını da teşkil ettiği söylenebilir. Tablo 7'de de görüldüğü üzere 1924'ten 1940'a kadar olan ihracat rakamları aynı zamanda üretim rakamlarımızdır. Bu nedenle Türkiye'nin krom ve konsantresi ihracatını daha sağlıklı incelemek için en sağlıklı verilerin 1990'lardan sonra olanlar olduğunu belirtmek gerekmektedir. 1995 'te 1.5 milyon tonu aşan krom cevheri ve konsantresi ihracat 2000 'li yıllarda çok ciddi bir şekilde gerilemiştir. Bu gerileme de sektördeki birtakım düzenlemeler (Özelleştirme gibi) büyük ölçüde etkili olmuş, aynı zamanda küresel ölçekteki ekonomik durgunlukta bu alana yansımıştır. 2002'de son yılların en düşük ihracat değerinin ardından düzenli bir şekilde 2008'e kadar dikkat çekici bir artış kaydedilmiştir. 2010 yılından itibaren ise ihracatımız 2 milyon tonun altına inmemiştir (Tablo 7). 
Türkiye'nin krom ihracatının ülkelere göre dağılımına baktığımızda da en fazla krom ihraç ettiğimiz ülkeler başta Çin (1.841.335 ton) olmak üzere sırasıyla İsveç (133.674 ton), Rusya Federasyonu (56.777 ton), Belçika (29.180 ton), Hollanda (24.536 ton), Hindistan (13.605 ton), Ukrayna (7.654 ton) ve Hong Kong (7.049)'dur (TÜİK, 2014). 2012 y1l itibariyle Türkiye toplam 27 ülkeye krom cevheri ve konsantresi ihraç etmiş olmakla beraber söz konusu bu 8 ülkeye yapılan toplam 2.113.810 tonluk ihracat toplam krom ihracatımızın \% 99.3'ünü teşkil etmektedir.

\section{SONUÇ}

Bulunmasının ardından çoğu madene göre çok kısa bir tarihi geçmişi söz konusu olan krom bu zaman zarfında da hızlı bir gelişim sürecine girmiş ve stratejik kaynaklar içerisinde yerini almıştır. Günümüzde çok geniş bir kullanım alanı bulunan kromun çoğu ülkede ekonomik değer taşıyan yatakları tükenmiş, bir kısmında da tükenme noktasına yaklaşmıştır. Bununla birlikte kroma alternatif bir kaynağın henüz bulunmuyor oluşu da söz konusu cevheri günden güne daha da kıymetli hale getirmektedir.

Türkiye, keşfinin ardından kısa süre sonra krom madenciliğine başlayan az sayıdaki ülkelerden biridir. Buna karşılık 150 yıldan fazladır doğrudan doğruya satılabilir yüksek tenörlü (\% 35) $\mathrm{Cr}_{2} \mathrm{O}_{3}$ yataklarının büyük bir bölümü tükenmiş krom madenciliğimiz dünya pazarlarındaki düşük fiyatla piyasaya sürülen krom cevheriyle de rekabet etmesi güçleşmiştir. Türkiye artık daha derin ve düşük tenörlü yataklardan üretim yapmak zorundadır. Bu da pahalıya mal olmaktadır. Gerçi stratiform yataklarda çoğunlukla yeraltı madenciliği yapıldığından ve gittikçe daha derine inildiğinden bunların da üretim maliyeti artmakta ise de Türkiye'de verim düşük, işçilik ise diğer ülkelere göre daha yüksektir.

Gerek yerli sanayinin hammadde güvenliğini sağlamak gerekse diş talebi karşılamak için bilinen rezervleri işletmek biryandan da yeni rezervler bulmak amacıyla araştırmaların yapılması gerekmektedir. Günümüzde sistemli araştırmalar olmaksızın yeni rezervlerin bulunması ve yatağın jeolojisi iyi bilinmeden gerçekleştirilen işletme çalışmalarını sürdürebilmek gittikçe güçleşmekte ve de sağlıklı bulunmamaktadır. Zaten yetersiz olan krom çalışmalarına ilave olarak mevcut bilgilerin de çoğunun eski olması (Büyük bir kısmı 1980'lere ait veriler) ve bu alanda mevcut durumumuzu tam olarak bilemiyor oluşumuz sektörde uzun vadeli sağlıklı planlar yapılmasının önündeki en büyük engellerin başında gelmektedir. İvedilikle mümkün ve muhtemel rezervlerin durumu netleştirilmeli aynı zamanda görünür rezervlerin yatak durumları bu alandaki teknik gelişmeler 1şığında aydınlatılmalıdır. Çoğu ülkenin stratejik kaynaklar kategorisinde değerlendirmiş olduğu krom madenciliği için yapılacak çalışmalar ancak sağlıklı bir Türkiye Krom Envanteri'nin çıkarılmasıyla mümkün olabilir.

Dünyanın giderek artan krom talebi doğrudan satış imkanı olmayan düşük tenörlü krom kaynaklarımızı zenginleștirme ve cevher hazırlama işlerinin değerlendirilmesi ile karşılanabilir ve diğer ülkelerle rekabet edilebilir. Ancak Türkiye'nin henüz düşük tenörlü krom potansiyeli uygun teknikle, düşük maliyetle ve verimli işletme imkanlarına sahip değildir. Türkiye'nin krom pazarındaki pozisyonunu koruması ve bu alanda daha da ilerleyebilmesi açısından altyapı çalışmaları planlanırken potansiyelin bilinmesi ve mevcut tesislerin işlerliği dikkatle incelenmelidir. Özellikle 2000 yılından sonra birçok yeni krom zenginleştirme tesisi kurulmuş olmakla birlikte düşük tenörlü kromitleri zenginleştirme konusunda çabalar yetersiz kalmıştır. Ayrıca mevcut tesislerde verim ve kapasite kullanımı da düşüktür. Çoğu tesislerde atığa giden cevher kaçağı \% 6'dan fazladır. Geçmiş yıllarda kaçak 
oranının \% 19 seviyesine kadar çıktığı bilinmektedir. Oysaki günümüzde \% 6' dan fazla $\mathrm{Cr}_{2} \mathrm{O}_{3}$ içeren eski konsantre atıkları önemli bir kaynaktır. Bu atıklardaki ince kromitin kazanılması cazip bir firsat olarak görülmekte, ancak bu firsatın değerlendirilmesi ise üst düzeyde teknolojik donanıma sahip işletmelere bağlıdır. Fakat Türkiye'de değil zenginleştirme tesislerinde genel olarak krom madenciliğimizde mekanizasyon hala çok düşük seviyelerde olup emek yoğun bir faaliyet olarak devam etmektedir. Bu da Türkiye'nin rekabet gücünü kıran bir diğer olumsuz etmen olarak karşımıza çıkmaktadır.

Krom madenciliğinde belirlenecek politikalar ve alınması gereken tedbirler sektör için hayati önem taşımaktadır. Geçmişte bu alanda rakipsiz olan Türkiye zaman içerisinde oldukça gerilemiştir. Daha önceleri önemli krom ihracatçısı olan ülkelerin ilerleyen yıllarda tükenen rezervleri ve artan iç talepleri doğrultusunda dışa bağımlı hale gelmeleri dikkat çekici örneklerdir (Hindistan gibi). Gerek 5 Yıllık Kalkınma Planı'nda gerekse madencilik ve tabii kaynaklar düzenleme kurumlarında krom ayrıca ele alınmalıdır. Kullanım alanlarının oldukça stratejik ve temel alanlar olduğu göz önüne alınıp henüz yeri doldurulabilir bir kaynak olmayan krom için ayrıca yasal düzenlemeler getirilmelidir. Türkiye bu kapsamda ilk olarak işlenmiş krom ve ferrokrom ihracatçısı olma yolunda tedbirler almalıdır. 2000 yılından itibaren devletin bu sektörden bütünüyle çekilmesine karşılık denetleme yine ulusal çıkarlar doğrultusunda Bakanlık tarafından oluşturulacak bir komisyona bırakılmalıdır. Mutlaka bir Krom Bank veya Krom Borsası oluşturulmalı ve sektörün geleceğe yönelik sağlıklı girişimler için stratejik planlar bahsi geçen kuruluşların direktifleri doğrultusunda yapılmalıdır. Çalışmamızda sıkça dile getirdiğimiz gibi salt Türkiye'de değil dünya genelinde krom üretim ve ticareti çok istikrarsız bir sektör olup kendi adımıza bunun sağlıklı işler hale gelmesi için tedbirler alınması gerekmektedir.

Mevcut kaynakların iyi değerlendirilmesi özellikle de bizim gibi sanayileşmekte olan ülkeler için hayati önem arz etmektedir. Günümüzde çoğu krom üreticisi ülkeler artık paslanmaz çelik üretmektedirler. Türkiye'de mutlaka kromit yerine paslanmaz çelik üretip ihraç etmelidir. Bu noktada da krom üreticisini teşvik ve destek amaçlı ulaştırma, altyapı tesisleri için uzun vadeli ve düşük faizli krediler, vergi kolaylığı yanında enerji konusunda da destek olunmalıdır. Nitekim sadece 1 ton krom metali imalatı için 6000 ila $10.000 \mathrm{kwh}$. elektrik enerjisi gerekmektedir ki bu da tonlarca üretimi söz konusu olan bir işletme için dikkat edilmesi gereken bir husustur. Son olarak da krom alanında Ar-Ge çalışmalarına ağırlık verilmesi, hurda kromların ne şekilde değerlendirilebileceğinin araştırılması bu stratejik kaynak konusunda Türkiye'nin elde edeceği kârı artırma noktasında önemli katkılar sağlayacaktır.

\section{REFERENCES}

- Anonim, (2011). “Chrome's Colourful History”, International Chromium Development Association, www.icdacr.com (Son erişim: 15.09.2014).

- Can, E., (2008). "Aladağ (Adana - Kayseri Arasi) Krom Yataklarının Yıllara Göre Üretim Envanterinin Çıkarılması", Çukurova Üniversitesi Fen Bilimleri Enst., Yayınlanmamış Yüksek Lisans Tezi, s. 82, Adana.

- Çakmak, İ., (2006). "Elazı ğ-Guleman Yöresi Kromit Cevheri Yataklarının Analizi ve Analiz Sonuçlarına Göre Kullanım Alanlarının Araştırılması”, Doğu Anadolu Bölgesi Araştırma ve Uygulama Merkezi Dergisi, Cilt: 4, Sayı: 2, s. 20 - 24, Elazığ. 
- Daş, B., Arık, F., Öztürk, A., Altay, O., (2012). "Krom Madenciliği ve Geçmişten Günümüze İnsanlık Tarihi Üzerindeki Etkileri”, Batman Üniversitesi Yaşam Bilimleri Dergisi, Cilt: 1, Sayı: 2, s. 77 - 88, Batman.

- Doğanay, H., (2011). "Türkiye Ekonomik Coğrafyası", Pegem Akademi Yayınları, Ankara.

- Doğanay, H., Altaş, N.T., (2013). "Doğal Kaynaklar”, Pegem Akademi Yayınları, 5. Bask1, s. 396, Ankara.

- DPT, (2001). "8. Beş Yıllık Kalkınma Planı Madencilik Ö.İ.K. Raporu (Metal Madenler Alt Komisyonu Krom Çalışma Grubu Raporu)", DPT: 2626, ÖİK: 637, s. 66, Ankara.

- DPT, (2007). “9. Beş Yıllık Kalkınma Planı Madencilik Ö.İ.K. Raporu”, Yayın No: DPT: 2739 - ÖİK: 690, s. 192, Ankara.

- Engin, T., (1986). “Türkiye Maden Yatakları ve MTA’nın Maden Aramacılığındaki Yeri”, MTA Yayınları No: 194, s 21, Ankara.

- Eldem, V., (1970). “Osmanlı İmparatorluğunun İktisadi Şartları Hakkında Bir Tetkik”, Türkiye İş Bankası Kültür Yayınları, s. 327, Ankara.

- Enver, S., (1931). “Türkiye ve Krom”, Milliyet Matbaası, s. 77, İstanbul.

- Gökçe, A., (2009). "Maden Yatakları”, III. Baskı, Cumhuriyet Üniversitesi Yayınları: 111, s. 336, Sivas.

- Karahan, S., Özkan, Y.Z., (2011). “Türkiye Krom Madenciliğinde Güncel Eğilimler ve Yeni Arayışlar", Türkiye 22. Uluslararası Madencilik Kongresi ve Sergisi, 11 - 13 Mayis 2011, s. 17 - 27, Ankara.

- Karakaş, N., (2010). “İkinci Dünya Savaşı Yıllarında Türkiye'nin Krom Satışı ve Müttefik Politikaları”, Ege Üniversitesi Tarih İncelemeleri Dergisi, Cilt: XXV., Sayı: 2, s. $447-482$, İzmir.

- Kıdıman, F. B., (2009). "Düşük Tenörlü Krom Cevherlerinin Zenginleştirilmesinin Araştırılması", Çukurova Üniversitesi Fen Bilimleri Enst., Yayınlanmamış Yüksek Lisans Tezi, s. 81, Adana.

- Koca, N., Koca, M.K., (2012). "Türkiye'de Madencilik ve Enerji Kaynakları", Türkiye Coğrafyası ve Jeopolitiği, (Ed. Hakkı Yazıcı, Mehmet Kürşat Koca), Pegem Akademi, III. Bask1, s. 266 - 280, Ankara.

- MTA, (1942). "Umumi Maden Durumu - 1941 Yılının İlk 9 Ayında Madenciliğimiz”, MTA Enstitüsü Mecmuası, Sene: 7, Sayı: 1/26, Ankara.

- MTA, (2009). “Türkiye Yer Altı Kaynakları İllere Göre”, Yerbilimleri Kültür Serisi 5, s. 602, Maden Tetkik ve Arama Genel Müdürlüğü, Ankara.

- Özdemir, N., (2010). "Madenler ve Enerji Kaynakları”, Genel Beşeri ve Ekonomik Coğrafya (Ed. Cemalettin Şahin), Gündüz Eğitim ve Yayıncılık, s. 209 - 256, Ankara.

- Özsoy, O., Yavilioğlu, C., Delice, G., Karagöl, E.T., (2011). "Türkiye'de Özelleştirilen Şirketlerin Performans Analizleri”, Özelleştirme İdaresi Başkanlığı, s. 308, Ankara.

- Rüstow, A., (1944). "İktisadi Coğrafya", Cilt: II., İstanbul Üniversitesi Yayınlarından No. 238, İktisat Fakültesi No. 26, s. 146, (Çev. Halid İlteber), İstanbul.

- Soykan, F., Mutluer, M., (1995). "Türkiye'de Madencilik ve Maden Yataklarının Coğrafi Dağılışı”, Ege Coğrafya Dergisi, Sayı: 8, s. 37 - 56, İzmir.

- Taşlıgil, N., (2005). “Türkiye'nin Ekonomik Coğrafyası”, Çantay Kitabevi, İstanbul.

- Wijkerslooth, P. de, (1942). "Türkiye ile Balkanlarda Krom Cevheri Zuhuratı ile Bu Ülkelerin Büyük Tektoniğine Olan Münasebetleri”, MTA Enstitüsü Mecmuası, Sene: 7, Say1: 1/26, s. 35 - 75, Ankara. 
- Zeytinoğlu, E., (1970). “Türkiye Ekonomisi Dersleri”, Kutulmuş Matbaası, s. 591, İstanbul.

- Yararlanılan İnternet Siteleri:

- http://www.migem.gov.tr/ (Maden İşleri Genel Müdürlüğü)

- http://www.immib.org.tr/tr/default.asp (İstanbul Maden ve Metaller İhracatçı Birlikleri)

- https://www.bgs.ac.uk/mineralsuk/statistics/worldStatistics.html (British Geological Survey)

- http://www.enerji.gov.tr/index.php?dil=tr\&sf=anasayfa (T.C. Enerji ve Tabii Kaynaklar Bakanlıği)

- http://www.dedemanmadencilik.com/ (Dedeman Madencilik)

- http://www.etimet.com/ (ETİ Elektrometalürji A.Ş.)

- http://minerals.usgs.gov/products/index.html (U.S. Geological Survey)

- http://www.maden.org.tr/genel/bizden_detay.php?kod=3334\&tipi=23\&sube=0

- http://tuikapp.tuik.gov.tr/disticaretapp/menu.zul (TÜIK, Dış Ticaret İstatistikleri)

- http://tr.etikrom.com/ (ETİ Krom A.Ş.)

- http://www.jmo.org.tr/ (TMMOB Jeoloji Mühendisleri Odasi)

- (Son erişim tarihleri: 28.04.2015) 